\title{
Article \\ Comparison of Consumption and Renewable Sources of Energy in European Union Countries-Sectoral Indicators, Economic Conditions and Environmental Impacts
}

\author{
Anna Komarnicka 1,*(D) and Anna Murawska ${ }^{2}$ (D) \\ 1 Department of Organizational Innovation Management, Faculty of Management, UTP University of Science \\ and Technology in Bydgoszcz, 85-790 Bydgoszcz, Poland \\ 2 Department of Economics and Marketing, Faculty of Management, UTP University of Science and \\ Technology in Bydgoszcz, 85-790 Bydgoszcz, Poland; anna.murawska@utp.edu.pl \\ * Correspondence: anna.komarnicka@utp.edu.pl
}

check for

updates

Citation: Komarnicka, A.;

Murawska, A. Comparison of

Consumption and Renewable Sources

of Energy in European Union

Countries-Sectoral Indicators,

Economic Conditions and

Environmental Impacts. Energies 2021,

14, 3714. https://doi.org/10.3390/

en14123714

Academic Editor: Robert Karaszewski

Received: 17 May 2021

Accepted: 18 June 2021

Published: 21 June 2021

Publisher's Note: MDPI stays neutral with regard to jurisdictional claims in published maps and institutional affiliations.

Copyright: (c) 2021 by the authors. Licensee MDPI, Basel, Switzerland. This article is an open access article distributed under the terms and conditions of the Creative Commons Attribution (CC BY) license (https:/ / creativecommons.org/licenses/by/ $4.0 /)$.

\begin{abstract}
The use of energy is a precondition for global economic and civilisational development. However, the growing demand for energy is depleting traditional energy resources and, most importantly, causing environmental pollution, mainly through the emission of greenhouse gases. As energy is necessary for the functioning of all sectors of the economy, such as industry, services, transport as well as households, these sectors are the largest contributors to energy consumption. Renewable energy sources are an alternative to generating energy from conventional fossil fuels. The main objective of this paper was to determine and compare the level, trends and variation in energy consumption by different economic sectors in countries of the European Union in 2010-2019. An analysis of the share of renewable energy consumption in different economic sectors was also carried out, as well as an assessment of the relationship of these indicators with the level of economic development of the countries and environmental impacts in the form of greenhouse gas emissions from energy consumption. To explore the topics under discussion, a dozen of indicators have been considered in the article. The source of empirical data collected was the European Statistical Office. The researched period covered the years 2010-2019. The empirical data was statistically analysed. The article considers changes in the values of the studied indicators, differentiation between countries and the results of correlation and regression analysis. As shown by the data from 2010-2019, the countries of the European Union vary significantly in respect of primary and final energy consumption. The highest final energy consumption occurs in the transport sector, followed by slightly lower consumption in the industrial sector and households sector and the lowest but also significant consumption in the commercial and public services sector. Since 2010, total primary and final energy consumption has decreased in the EU (27) countries. Total energy consumption and consumption by individual sectors in modern economies of the EU (27) countries are reflected on the one hand in economic development and on the other-in exacerbation of adverse climate changes. Therefore, all EU Member States, aware of their energy consumption and their own contribution to environmental pollution, should take effective and sustainable corrective action in this area as soon as possible.
\end{abstract}

Keywords: energy consumption; renewable energy sources; greenhouse gas emission; economic sectors; GDP per capita; comparison; European Union countries; variation

\section{Introduction}

Energy is recognised as a driver of a country's economic growth, an essential commodity and an important tool for holistic development, while sustainable economic growth requires sufficient and continuous availability of energy [1-3]. In other words, energy is fundamental for socio-economic growth but, in addition to its positive effects, it is one of 
the main suppliers of GHG emissions. [4-6]. Energy can be used for a variety of purposes and is acquired from many different sources [6] (p. 15).

Fossil fuels still represent the foundation of the global energy system [4]. At present, roughly $81 \%$ of the global total primary energy production comes from fossil fuels, of which oil accounts for $31.5 \%$, coal-26.9\% and natural gas-22.8\%. Biofuels secured $9.3 \%$, nuclear energy $-4.9 \%$ and hydropower-2.5\% of global energy supply in 2018. By contrast, only $2.1 \%$ of the world's primary energy comes from solar, wind, geothermal or biomass energy or other alternative energy sources. The above figures for total primary energy supply are based on world energy balances and have been retrieved from the International Energy Agency (IEA) [7].

It is well established that fossil fuels will be depleted in the future and their consumption is the largest contributor to greenhouse gas emissions [2,8]. The global increase in carbon dioxide concentrations from the burning of fossil fuels is a major driver of anthropogenic climate change that might lead to catastrophic environmental damage [6,9-12]. Heavy dependence on the predominant energy sources, i.e., fossil fuels, has resulted in a growing need to reduce the consumption of energy from conventional sources and replace it with energy obtained from renewable sources $[2,13,14]$. The use of renewable energy sources (RES) is gaining importance on European energy markets and is becoming an important factor in meeting global energy demand $[8,15]$. According to numerous studies, increased intensity of RES use may assist in the transformation towards a low-carbon future, ensure diversity of energy supply and in the long term increase energy security for energyimporting countries and reduce dependence of fossil energy supplies [2,4,8,10,11,14,16-18]. Enhancing renewable energy supplies may also play an important role in reducing global warming and combating climate change by limiting the levels of harmful particulate matter (smog) and reducing energy-related greenhouse gas emissions [4,18-21].

Concern for the natural environment and raising the share of renewable energy sources in all countries and sectors, requires implementation of regulatory policies and necessitates systemic changes towards a more sustainable economy [13,22-25]. Therefore, in Europe, the European Union has not only assumed the responsibility to combat climate change but has also for many years taken a number of measures to shape and promote energy policy reform in the context of implementing energy transition-moving the use of fossil fuels to renewable energy sources $[16,22,26,27]$. The legal basis of the European Union's climate and energy policy is comprised of, inter alia, the EU Emissions Trading System (EU ETS) [28], the Directive on the promotion of the use of energy from renewable sources (RED II) $(2018 / 2001)$ [29], the Directive on energy efficiency (2018/2002) [30] and the Directive on common rules for the internal market for electricity (2019/944) [31]. All of the abovementioned policies were being developed at the same time and reformed practically concurrently as part of individual policy packages [32]. The EU ETS, which is the flagship example of EU climate policy and the world's first and largest carbon dioxide emissions trading scheme, was introduced in $2003(2003 / 87 / E C)$ [33] to promote the reduction of greenhouse gas emissions in a cost-effective and economically efficient manner [22,34,35]. The EU emissions trading system was reformed in 2015 by the EU Decision $(2015 / 1814)$ "concerning the establishment and operation of a market stability reserve for the Union greenhouse gas emission trading scheme" [36] (p. 1). However, a more substantial revision of the previous Directive was made in 2018 by Decision of the European Parliament and of the Council (EU) (2018/410) to enhance cost-effective emission reductions and lowcarbon investments [35]. The revised EU ETS Directive of 2018 regulates the fourth trading period starting in 2021. This objective will be achieved through a package of interlinked measures. First, the sectors covered by the EU ETS must reduce emissions by 43 per cent below 2005 levels by 2030 [32,35]. In addition, to accelerate the process of reducing these emissions, from 2021 onwards the total number of emission allowances will be reduced at a rate of 2.2 per cent per year [32,35]. A second major EU climate and energy policy instrument is the 2018 Directive of the European Parliament and of the Council (EU) on the promotion of the use of energy from renewable sources (RED II) $(2018 / 2001)$, which 
amended the previous 2009 Renewable Energy Directive (RED) (2009/28/EC) [29,32]. The EU 2030 climate and energy framework sets targets for increasing the share of renewable energy in the overall EU energy balance [10]. Thereby, a binding EU common target was established for all Member States to achieve at least a 32\% share of renewable energy by $2030[18,29]$. Another important element of European energy and climate policy and one of the main drivers of sustainable development is energy efficiency [37]. As Cabeça et al. [38] highlight, it is one of the simplest and cost-effective tools to reduce energy consumption while contributing to greenhouse gas (GHG) reduction. The new Directive of the European Parliament and of the Council (EU) (2018/2002), in force since December 2018, amended the Directive of 25 October 2012 (2012/27/EU) on energy efficiency in order to adapt it to a time perspective reaching 2030 [30]. According to the provisions of the new Energy Efficiency Directive, a target of reducing primary or final energy consumption by at least $32.5 \%$ by 2030 at the EU level has been set [30]. Likewise, the Directive of the European Parliament and of the Council (EU) (2019/944) of 5 June 2019 introduced a number of amendments to existing directives which made an important contribution to the creation of an internal market for electricity [31]. Meanwhile, in December 2019, the European Commission presented the European Green Deal for the European Union and its citizens in which it commits to tackling climate and environmental challenges. This new strategy "aims to transform the EU into a fair and prosperous society, with a modern, resourceefficient and competitive economy" [39] (p. 2) with zero net greenhouse gas emissions by 2050 where economic growth is decoupled from the use of natural resources It also aims to preserve and improve the EU's natural capital, protecting the health of the population from environmental risks and negative impacts, while supporting an overhaul of the energy system $[23,39,40]$. The European Commission's Communication also presents an initial roadmap with key measures, new legislation and legislative initiatives needed to achieve climate neutrality by 2050 and other set targets [39]. As a result, all regulations, directives, recommendations and other strategic documents implemented for many years by the EU as part of its climate and energy policy are intended to help the Member States achieve the Sustainable Development Goals [41].

In view of the foregoing, analysis of the current situation and forecasting with respect to the energy sector is not only an important research topic in the literature but it is also a key element in shaping long-term policy for sustainable economic development [19]. "An important aspect is the relationship between the economy and its major industries, energy and environment" ([42], p. 74). Therefore, the European Union countries' development of climate and energy policy should be systematically monitored and analysed [16].

The outline of the subsequent portion of the paper is as follows: after the introduction, the second chapter of the paper reviews the existing bibliographical references on studies aimed at demonstrating the relationship between energy consumption, economic growth and pollutant emissions. It discusses the theoretical basis and summarises the experience of global energy transition wherein the use of energy from renewable sources plays a central part. This is followed by a justification of the methodology and a description of the indicators used and the methodology adopted in statistical analysis in the third section. The fourth and fifth section present the results of the study and a discussion taking into account prior empirical studies on the subject. Finally, key conclusions are arrived at together with concluding remarks which may be helpful for decision making and implementation of future actions by individual European Union countries in relation to their energy and environmental policy, important for the development of a low-carbon economy. Thereby, the goal of ensuring a permanent reduction in environmental pollution, and the pursuit of sustainable development of the energy sector throughout Europe, will become achievable.

\section{Literature Review}

In the literature, three strands of research may be identified relating to the energy consumption, economic growth and pollutant emissions nexus $[4,10,43]$. The abovenamed 
nexus can be split into three types of correlations: growth-energy, growth-environment and growth-energy-environment [9] (p. 6).

The first group of studies focuses on the economic growth and energy consumption nexus $[4,10,43]$. The study of this nexus has been the focus of many researchers over the past three decades and the studies differ either in the method or the type of energy considered $[1,2,5,12,18,20,44-47]$. Most of the literature in this research area is oriented towards the role of energy in driving economic growth or investigation of the direction of causality between of these variables [2]. A large number of empirical studies assess these relationships using Granger causality and a cointegration model. It should be emphasised that the study of the correlation that exists between the consumption of sustainable energy and the economic development level is of enormous significance for both green and energy policy measures [46].

Šikić [1] in his research found that renewable and non-renewable energy consumption has a long-term impact on economic growth rates. However, his results are different for developed and post-transition EU countries. According to the results, in the 16 "developed EU countries renewable energy consumption has a negative impact on economic growth, while non-renewable energy consumption has a positive impact" ([1], p. 475). In contrast, in the 11 post-transition EU countries the results are reversed-when the consumption of renewable energy rises by $1 \%$, the GDP will increase by $0.68 \%$.

Chica-Olmo et al. [20] in their paper investigated the spatial relationship between GDP and renewable energy consumption for 26 European countries with Durbin's model. Their study indicates that if a country increased its renewable energy consumption by $1 \%$, this will have an impact on the GDP of neighbouring countries of $0.025 \%$ to $0.056 \%$ based on interconnections between the countries under consideration.

In their research, Saint et al. [44], Soava et al. [45] and Smolović et al. [46] found a positive, long-term and statistically significant relationship between renewable energy consumption and economic growth in EU countries. However, further results obtained by Smolović et al. [46] indicate that in the short-term, the effect of renewable energy consumption for economic activity was found to be negatively in the new Member States (that became members after 2004), while in the traditional Member States it had no statistically significant effect.

A study by Khribich et al. [12] using a panel dataset for 27 high-income countries (Gross National Income per capita of $\$ 12,376$ or more) established a short- and long-term causal relationship between renewable energy consumption and social development. The study found that "social development affects significantly the renewable energy consumption in the long run but not in the short-run" ([12], p. 20).

In contrast, a study by Kahouli [5], which analysed a panel dataset for 34 OECD countries using three models of growth-energy nexus, energy-growth nexus and two-way linkages between them, confirmed a feedback effect between economic growth and energy. The study concluded that there is a strong and significant link between the two. This means that energy consumption and economic growth influence each other.

In the MINT countries (Mexico, Indonesia, Nigeria and Turkey), on the other hand, Odugbesan and Rjoub [2] revealed that the unidirectional causal relationship between energy consumption and economic growth held true for Nigeria and Indonesia, while Mexico and Turkey were consistent with the feedback hypothesis, which indicates a bidirectional relationship between the two variables.

It should be noted that in spite of the existence of many academic studies on the subject, the existence or direction of causality between energy consumption and economic growth is not agreed upon [1]. In fact, four hypotheses have been identified in relation to the causal relationship under study $[18,25,48]$ :

(1) the growth hypothesis validates a unidirectional causality as between energy consumption and economic growth,

(2) the environmental protection hypothesis suggests a unidirectional causality between economic growth and energy consumption, 
(3) the feedback hypothesis implies the existence of mutual interdependence of energy consumption and economic growth (bidirectional causality),

(4) the neutrality hypothesis assumes no significant causality between economic growth and energy consumption.

The second strand of research focuses on the economic growth and environmental pollution nexus $[11,17,49-54]$. This branch of research attempts to verify the environmental Kuznets curve (EKC) hypothesis [4,10,11,43,53]. "The EKC hypothesis accepts that environmental degradation increases alongside with per capita income up to a certain threshold point" ([48], p. 203). Once this point is reached, environmental degradation begins to decrease forming an inverted "U" shape between the two variables. As Mahdi Ziaei [54] points out, "the main reason for studying carbon dioxide emissions is that they play a central role in the current debate on environmental protection, climate change abatement, energy security, sustainable use of available resources and sustainable development" ([54], p. 753). According to the study by Mahdi Ziaei [54], the relationship between GDP growth and $\mathrm{CO}_{2}$ emissions shows both bidirectional and unidirectional causality. The study concludes that the influence of energy consumption on $\mathrm{CO}_{2}$ emissions is important in the group of developing and developed countries alike, with varying impacts.

Al-Mulali et al. [17], in their study, investigated the effect of variation in electricity generation from renewable energy sources and the impact of five renewable energy sources on $\mathrm{CO}_{2}$ emissions in 23 selected European countries between 1990 and 2013. The authors demonstrated the "existence of long-run causality between $\mathrm{CO}_{2}$ emission, GDP growth, financial development, and and electricity production from combustible renewables and waste generation" ([17], p. 636). The study also found that GDP growth, urbanisation and financial development were the major drivers that positively affect $\mathrm{CO}_{2}$ emissions, to the contrary, trade openness reduces $\mathrm{CO}_{2}$ emissions in the long run.

An additional contribution to this area of research can be found in the paper by Khan et al. [50], in which a global panel dataset for 192 countries was used to analyse the influence of renewable energy consumption, carbon dioxide emissions and financial development on one another. According to the results, the influence of renewable energy consumption on carbon dioxide emissions is negative, while financial development has an increasing effect on carbon dioxide emissions. The study has also shown that both renewable energy consumption and $\mathrm{CO}_{2}$ emissions affect financial development in a positive and significant manner.

Results of prior research also allowed Waheed et al. [49] to draw new conclusions about the relationship between carbon dioxide emissions and economic growth. The results of their analyses suggested that the function of economic growth in carbon dioxide emissions is largely observed in high developed countries. Developing countries require large amounts of energy to meet industrial, urbanisation and transport needs but this comes at a cost of environmental degradation and results in increased carbon dioxide emissions.

Another perspective including an assessment of long-term and short-term correlations between renewable energy use, $\mathrm{CO}_{2}$ emissions and municipal waste recycling has been provided in a study published by Bayar et al. [52]. The findings of that study showed no significant correlation between recycling rate, renewable energy and $\mathrm{CO}_{2}$ emissions. Nevertheless, over the long term, "both recycling and renewable energy use tend to drive a decline in $\mathrm{CO}_{2}$ emissions", so that "improvements in recycling and renewable energy use are expected to make a significant contribution to environment sustainability" ([52], p. 7).

Sterpu et al. [11] published a paper in which they used a quadratic model as well as a cubic model to estimate the shape of the environmental curve and test the Kuznets hypothesis (EKC). Their study sought to determine the relationship between per capita greenhouse gas emissions, GDP, gross energy consumption and renewable energy consumption for a panel of 28 EU countries over the 1990-2016 period. The results revealed inconclusive evidence for the environmental Kuznets curve (EKC) hypothesis. However, estimations for all models showed that an increase in gross energy consumption leads to an 
increase in GHG emissions, whereas an increase in renewable energy consumption leads to a decrease in GHG emissions.

In their study, Filimonova et al. [51] have evaluated the impact of various macroeconomic factors on environmental pollution indicators in OECD countries in 1990-2016. On the factor end, their model used economic, technological and demographic factors, i.a. "population size, gross domestic product, industrial production per capita, technological level, the share of industry and agriculture in GDP and the share of exports and imports" ([51], p. 28). The authors proposed and built new mathematical models that have the potential to be applied to long-term policy development and "to predict the possible consequences of economic growth in Europe and the world" ([51], p. 31).

An extended EKC model was used in an article by Lapinskienè et al. [53] to investigate the relationship between GDP, greenhouse gas emissions and several other additional factors (e.g., energy consumption, energy taxes, R\&D activities) using panel data from 22 EU countries between 1995 and 2014. In general, their study confirmed the existence of an inverted U-shaped curve relationship. The results indicate that prospective path of the EKC may depend on a country's level of development. In countries that have reached a higher level of development and have reached the EKC threshold point, GDP growth could have a positive impact on GHG levels.

The third strand is an approach that has built on the basis of the last two groups of studies, analysing the nexus among economic growth, environmental pollution and energy consumption $[4,10,43]$. A review of selected empirical studies and existing literature on this topic will be presented in the Discussion section.

The literature review justifies a conclusion that most of the previous studies employed GDP growth $[17,51,55]$, primary and final energy consumption $[9,12,16,55]$, share of renewable energy in energy consumption $[9,19]$, urbanisation $[2,17]$, trade openness $[17,50,56]$, financial development $[17,50,54]$, energy intensity [19,57], dependence on energy supply $[9,19,58]$, etc. as indicators of economic activity. In numerous available publications referenced as part of literature on the links between the economy, energy and environment, other researchers have also evaluated the impact of various socio-economic factors, demographic factors [51], technological factors [51] and other aspects and conditions that affect the ecosphere, the energy sector and the dynamics of environmental indicators. In this regard, there is a vast number of studies that focus on aspects of energy structure, energy and environmental R\&D activities [53,58], public awareness [8,59-61], energy efficiency [37,62-65], eco-innovation [12], eco-efficiency [66], natural resources [47,67], municipal waste recycling [52], energy policy [60,65,68,69], education [8], health $[23,41]$, the tourism sector [25], COVID-19 epidemic [70], energy prices [57,60], taxation [53,71], renewable energy technologies $[22,27,72]$, etc., very often in connection with economic growth $[46-49,53,63,73]$, energy planning system $[59,63,74]$, energy resource management system $[38,68]$ or diversification of the economic structure.

\section{Materials and Methods}

Access to energy and the level and manner of its production and consumption represent some of the preconditions of economic development of a country and improvement of the living standards and quality of life of its population. On the other hand, excessive and irresponsible consumption of energy by various economic sectors causes degradation and destruction of the natural environment and thereby reduces the quality of life of societies, generating huge environmental costs [75]. In view of the positive and negative effects of energy use, the primary objective of this study was to compare the European Union Member States in terms of energy consumption in total and by individual economic sectors, to compare the share of renewable energy sources, the environmental impacts in the form of greenhouse gas emissions from energy and the impact of economic development of the countries on energy consumption. The following specific objectives have been accomplished: first, assess the level of variation between EU countries with regard to energy consumption in total and by sectors such as industry, transport, commercial and 
public services and households; second, compare and evaluate renewable energy sources in general and in transport, electricity and heating and cooling; third, seek confirmation whether the level of energy consumption in total and by different sectors of the economy is related to methods of energy generation, the economic development of the countries and the environmental impacts in the form of greenhouse gas emissions; fourth, establish whether the level of energy consumption and the economic development of the countries is related to trends of change (increase or decrease) in energy consumption. Attainment of the objective of this article was intended to enable verification of the hypothesis assuming that European Union countries vary significantly in terms of energy consumption and production of renewable energy both in general and in individual sectors of the economy and that energy consumption increases significantly with increasing economic development of the countries and affects the level of greenhouse gas emissions from energy.

The source of empirical data was information collected by the European Statistical Office (Eurostat) [76]. Twenty-seven countries (objects) of the European Union were analysed. The researched period covered the years 2010-2019. In order to meet the objectives of the article, energy consumption variables were selected from a range of indicators monitoring the achievement of sustainable development goals. Consequently, a numerical database consisting of twelve indicators was created in Microsoft Excel and Statistica 13.3. The selection of indicators was informed by the expert method involving a discussion with independent experts on the validity of the choice of variables. The decision to select the final indicators depended on the availability of complete and up-to-date data for all 27 Member States of the European Union and a positive evaluation of the choice of variables by the experts. Consequently, a numeric array of indicators characterising: the level of primary energy consumption in total $\left(\mathrm{X}_{01}\right)$, final energy consumption in total $\left(\mathrm{X}_{02}\right)$ and by sectors such as industry $\left(X_{03}\right)$, transport $\left(X_{04}\right)$, commercial and public services $\left(X_{05}\right)$ and households $\left(X_{06}\right)$, the share of renewable energy in total $\left(X_{07}\right)$ and in transport $\left(X_{08}\right)$, in electricity $\left(X_{09}\right)$ and in heating and cooling $\left(X_{10}\right)$, the share of greenhouse gas emissions from energy $\left(X_{11}\right)$, and economic development measured by the classic indicator of GDP per capita $\left(X_{12}\right)$ was prepared. Indicator $X_{12}$ was included to examine whether economic growth in EU (27) countries entails an increase in energy consumption and, consequently, in environmental pollution as a result of greenhouse gas emissions from energy (Table 1).

The descriptive and graphical analysis of results of the study makes use of abbreviations of the names of the European Union Member States according to ISO 3166 Alpha-2 codes developed by the International Organisation for Standardisation [77]: Austria (AT), Belgium (BE), Bulgaria (BG), Croatia (HR), Cyprus (CY), Czech Republic (CZ), Denmark (DK), Estonia (EE), Finland (FI), France (FR), Germany (DE), Greece (GR), Hungary (HU), Ireland (IE), Italy (IT), Latvia (LV), Lithuania (LT), Luxembourg (LU), Malta (MT), Netherlands (NL), Poland (PL), Portugal (PT), Romania (RO), Slovakia (SK), Slovenia (SI), Spain (ES), Sweden (SE). In particular, energy consumption by EU countries in general and by countries with minimum and maximum values of the studied indicators was analysed.

The data was statistically analysed. Core descriptive statistics of the studied statistical population of EU countries have been used in the paper. Indices of the rate of increase or decrease $I_{t}$, coefficients of variation $V_{s}$, measures of distance $D$ and range $R$, correlation coefficients $r_{x y}$ and linear regression coefficients [78,79], inter alia, were calculated. Calculation of the indices of the rate of increase or decrease $I_{t}$ (in \%) was intended to express the level of growth of energy consumption in 2019 (and of other indicators) compared to the base year $2010\left(I_{t}=t_{2019}-t_{2010} \times 100-100\right.$ in \%). Growth values above zero indicate an increase in the level of energy consumption or renewable energy production, and values below zero-a decrease. To assess the variation of the studied countries, the coefficient of variation $V_{S}$ was used $\left(V_{S}=S / \bar{x} \times 100 \%\right.$, where, $\bar{x}$ and $S$ represent the arithmetic mean and standard deviation, respectively. The variation between the EU countries in energy consumption is significant when $\mathrm{V}_{\mathrm{s}}>10 \%$ ) [78]. Other measures that evaluate the variation between the countries are the measure of distance $\mathrm{D}(\mathrm{D}=\mathrm{max} / \mathrm{min})$ and the measure of range $\mathrm{R}$ ( $\max -\mathrm{min})$. In order to establish whether there are correlations (there is a 
relationship) between the studied indicators, correlation and regression analyses were performed in the course of the study. The correlation coefficient $r_{x y}$ and the coefficient of determination $\mathrm{R}^{2}$, inter alia, were used to test whether there were significant correlations between the variables studied.

Table 1. Indicators allowed for in the study of energy consumption in total and by individual sectors, renewable sources of energy, environmental impacts and economic conditions in EU (27) countries in 2010-2019.

\begin{tabular}{ccc}
\hline Variable & Data for & Variable Name \\
\hline X1 & Primary and final energy consumption in total and by individual sectors \\
\hline X2 & $2010-2019$ & $\begin{array}{c}\text { Per capita primary energy consumption in tonnes of } \\
\text { oil equivalent (TOE) per inhabitant }\end{array}$ \\
\hline X3 & $2010-2019$ & $\begin{array}{c}\text { Per capita final energy consumption in total in } \\
\text { tonnes of oil equivalent (TOE) per inhabitant }\end{array}$ \\
\hline X4 & $2010-2019$ & $\begin{array}{c}\text { Per capita final energy consumption in the industrial } \\
\text { sector in tonnes of oil equivalent } \\
\text { (TOE) per inhabitant }\end{array}$ \\
\hline X5 & $2010-2019$ & $\begin{array}{c}\text { Per capita final energy consumption in the transport } \\
\text { sector in tonnes of oil equivalent } \\
\text { (TOE) per inhabitant }\end{array}$ \\
\hline X6 & $2010-2019$ & $\begin{array}{c}\text { Per capita final energy consumption in the } \\
\text { commercial and public services sector in tonnes of } \\
\text { oil equivalent (TOE) per inhabitant }\end{array}$ \\
\hline
\end{tabular}

Share of renewable energy in final energy consumption in total and by sector-mitigation of energy consumption impacts

\begin{tabular}{|c|c|c|}
\hline $\mathrm{X} 7$ & 2010-2019 & $\begin{array}{c}\text { Share of total renewable energy in gross final energy } \\
\text { consumption in } \%\end{array}$ \\
\hline $\mathrm{X} 8$ & 2010-2019 & $\begin{array}{l}\text { Share of renewable energy sources in transport in } \\
\text { gross final energy consumption in } \%\end{array}$ \\
\hline X9 & 2010-2019 & $\begin{array}{l}\text { Share of renewable sources of electricity in gross } \\
\text { final energy consumption in \% }\end{array}$ \\
\hline $\mathrm{X} 10$ & 2010-2019 & $\begin{array}{l}\text { Share of renewable energy sources in heating and } \\
\text { cooling in gross final energy consumption in \% }\end{array}$ \\
\hline \multicolumn{3}{|c|}{ Share of total greenhouse gas emissions from energy-environmental impacts of energy consumption } \\
\hline $\mathrm{X} 11$ & 2010-2018 & $\begin{array}{c}\text { Greenhouse gas emissions from energy as \% of total } \\
\text { greenhouse gas emissions }\left(\mathrm{CO}_{2}, \mathrm{~N}_{2} \mathrm{O} \text { in } \mathrm{CO}_{2}\right. \\
\text { equivalent, } \mathrm{CH}_{4} \text { in } \mathrm{CO}_{2} \text { equivalent, } \mathrm{HFC} \text { in } \mathrm{CO}_{2} \\
\text { equivalent, } \mathrm{PFC} \text { in } \mathrm{CO}_{2} \text { equivalent, } \mathrm{SF} 6 \text { in } \mathrm{CO}_{2} \\
\left.\text { equivalent, } \mathrm{NF}_{3} \text { in } \mathrm{CO}_{2} \text { equivalent }\right)\end{array}$ \\
\hline \multicolumn{3}{|c|}{ Economic conditions of energy consumption } \\
\hline $\mathrm{X} 12$ & 2010-2019 & Real GDP per capita in EUR \\
\hline
\end{tabular}

\section{Results}

As the data from 2010-2019 shows, the countries of the European Union vary significantly in terms of primary and final energy consumption, with the variation decreasing steadily over the last decade (Table 2). While the coefficient of variation in 2010 for EU (27) countries for primary energy consumption was $V_{S}=45.9 \%$, in 2019 it was equal to $\mathrm{V}_{\mathrm{s}}=38.8 \%$, whereas for final energy consumption in $2010 \mathrm{~V}_{\mathrm{s}}$ was equal to $57.6 \%$ and in $2019 \mathrm{~V}_{\mathrm{s}}$ was equal to $48.2 \%$. The significant variation between the countries with regard to energy consumption is also confirmed by the coefficients of distance D and range $\mathrm{R}$. A positive aspect in the context of environmental impacts for Europe is a slight decline 
in primary energy consumption by the Member States. In 2010, the consumption was at 3.3 tonnes of oil equivalent (TOE) per inhabitant, decreasing to $3.0 \mathrm{TOE} /$ inhabitant in 2019. In contrast, while there has been a decrease in final energy consumption compared to 2010 , it is disturbing that the consumption remained constant at $2.2 \mathrm{TOE} /$ inhabitant in the recent 2015-2019 period. The slight decrease in the level of primary and final energy consumption in the EU (27) between 2010 and 2019 is also confirmed by the calculated indices $\mathrm{I}_{\mathrm{t}}, \mathrm{I}_{\mathrm{t} X 01}=-8.8 \%, \mathrm{I}_{\mathrm{t} X 02}=-5.2 \%$ (Table 2).

Table 2. Primary and final energy consumption in EU (27) countries in 2010-2019—statistics.

\begin{tabular}{|c|c|c|c|c|c|c|c|c|c|c|c|c|c|c|c|}
\hline \multirow{2}{*}{ Statistics for } & \multicolumn{6}{|c|}{ Primary Energy Consumption $\mathrm{X}_{01}$} & \multirow{2}{*}{$\mathbf{I}_{\mathbf{t}}$} & \multirow{2}{*}{ Statistics for } & \multicolumn{6}{|c|}{ Final Energy Consumption $X_{02}$} & \multirow{2}{*}{$\mathrm{J}_{\mathbf{L}}$} \\
\hline & 2010 & 2015 & 2016 & 2017 & 2018 & 2019 & & & 2010 & 2015 & 2016 & 2017 & 2018 & 2019 & \\
\hline $\mathrm{EU}(27)$ & 3.3 & 3.1 & 3.1 & 3.1 & 3.1 & 3.0 & -8.8 & EU (27) & 2.3 & 2.2 & 2.2 & 2.2 & 2.2 & 2.2 & -5.2 \\
\hline $\mathrm{X}_{\min } \mathrm{RO}$ & 1.6 & 1.6 & 1.6 & 1.7 & 1.7 & 1.7 & 1.2 & $\mathrm{X}_{\min } \mathrm{RO}$ & 1.1 & 1.1 & 1.1 & 1.2 & 1.2 & 1.2 & 10.8 \\
\hline$X_{\max } \mathrm{LU}$ & 9.1 & 7.3 & 7.1 & 7.2 & 7.3 & 7.3 & -20.1 & $X_{\max } L U$ & 8.5 & 7.0 & 6.9 & 7.0 & 7.2 & 7.1 & -17.1 \\
\hline $\mathrm{V}_{\mathrm{s}}$ & 45.9 & 40.7 & 40.5 & 38.7 & 39.6 & 38.8 & & $\mathrm{~V}_{\mathrm{s}}$ & 57.6 & 50.7 & 49.5 & 48.3 & 48.9 & 48.2 & \\
\hline $\mathrm{D}$ & 5.6 & 4.7 & 4.6 & 4.3 & 4.4 & 4.4 & & $\mathrm{D}$ & 7.7 & 6.4 & 6.1 & 5.9 & 5.9 & 5.8 & \\
\hline $\mathrm{R}$ & 7.5 & 5.7 & 5.6 & 5.5 & 5.7 & 5.6 & & $\mathrm{R}$ & 7.4 & 5.9 & 5.8 & 5.8 & 6.0 & 5.9 & \\
\hline
\end{tabular}

Key: $\mathrm{X}_{\min }$-minimum value for the country, $\mathrm{X}_{\max }-$ maximum value for the country, $\mathrm{V}_{\mathrm{s}}$-coefficient of variation in \% for EU (27) countries, $\mathrm{D}$-distance $(\mathrm{max} / \mathrm{min}), \mathrm{R}$-range $(\max -\min ), \mathrm{I}_{\mathrm{t}}$-fixed-base index $\mathrm{I}_{\mathrm{t}} 2019(2010=100)$ in \%. Source: own work based on [76].

The countries in the EU (27) that consume the least primary energy per inhabitant are: Romania (in $2019 X_{01}=1.7$ ), Malta $\left(X_{01}=1.7\right)$, Croatia $\left(X_{01}=2.0\right)$ and Portugal $\left(X_{01}=2.2\right)$, and for final energy: also Romania $\left(\mathrm{X}_{02}=1.2\right)$ and Malta $\left(\mathrm{X}_{02}=1.4\right)$ as well as Bulgaria $\left(X_{02}=1.4\right)$ and Greece $\left(X_{02}=1.5\right)$. At the other extreme, countries such as Luxembourg $\left(X_{01}=7.3 ; X_{02}=7.1\right)$, Finland $\left(X_{01}=5.1 ; X_{02}=4.6\right)$, Sweden $\left(X_{01}=4.5, X_{02}=3.1\right)$ and Belgium $\left(\mathrm{X}_{01}=4.3, \mathrm{X}_{02}=3.1\right)$ are ranked as countries with the highest consumption of both primary and final energy. The third largest final energy consumer is Austria $\left(X_{02}=3.2\right)$ (Figures 1 and 2). In the graphs showing primary $\left(\mathrm{X}_{01}\right)$ and final energy consumption $\left(\mathrm{X}_{02}\right)$ as well as the indices $\mathrm{I}_{\mathrm{t} \times 01}$ and $\mathrm{I}_{\mathrm{t} \times 02}$ for the period of 2010-2019, it can be observed that, in relative terms, the countries that have historically and currently consumed the most energy, both primary and final, have seen the largest decreases in energy consumption over the last decade (e.g., in Luxembourg, Belgium, Sweden, Finland), while countries with lower consumption have relatively more often experienced increases in energy consumption (e.g., Bulgaria, Poland, Hungary, Latvia, Lithuania, Romania) (Figures 1 and 2).

15.0

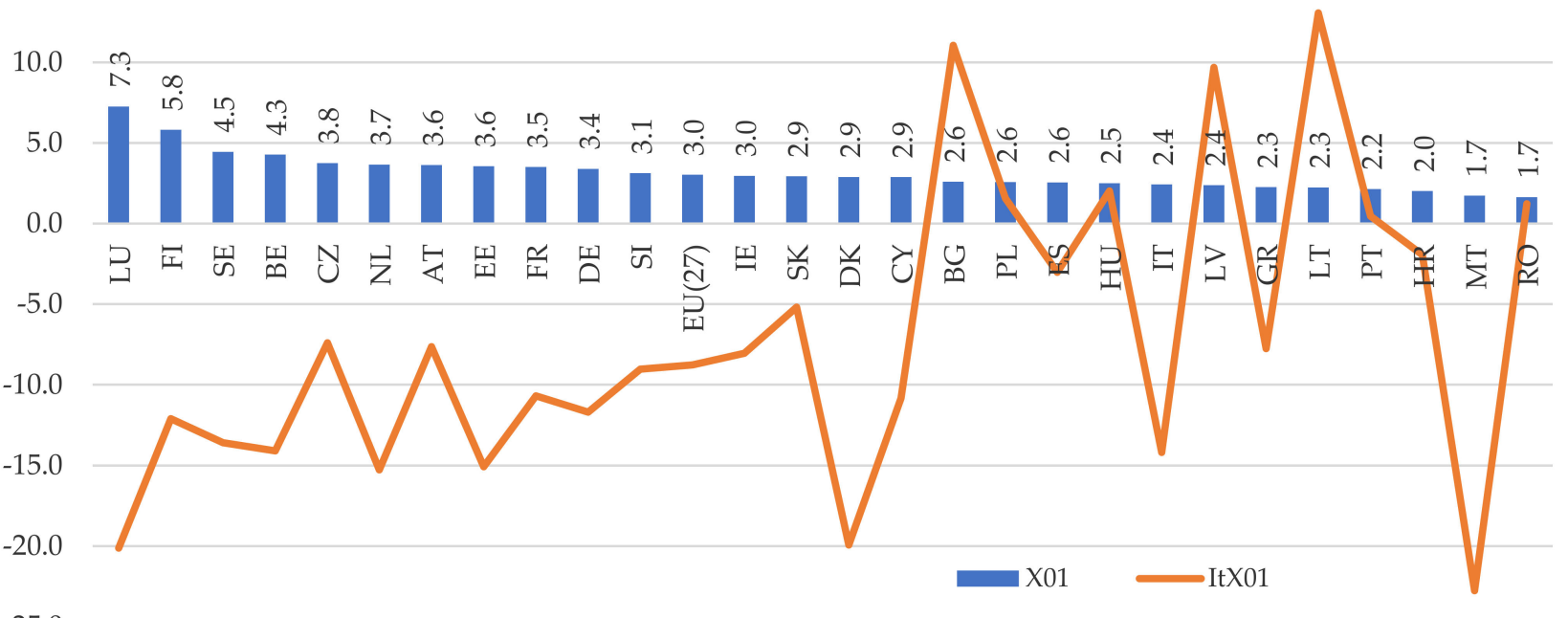

$-25.0$

Figure 1. A ranking of EU (27) countries according to their primary energy consumption in tonnes of oil equivalent per inhabitant $\left(\mathrm{X}_{01}\right)$ in 2019 and index $\mathrm{I}_{\mathrm{t} X 01}$ for $2019(2010=100)$. Source: own work based on [76]. 


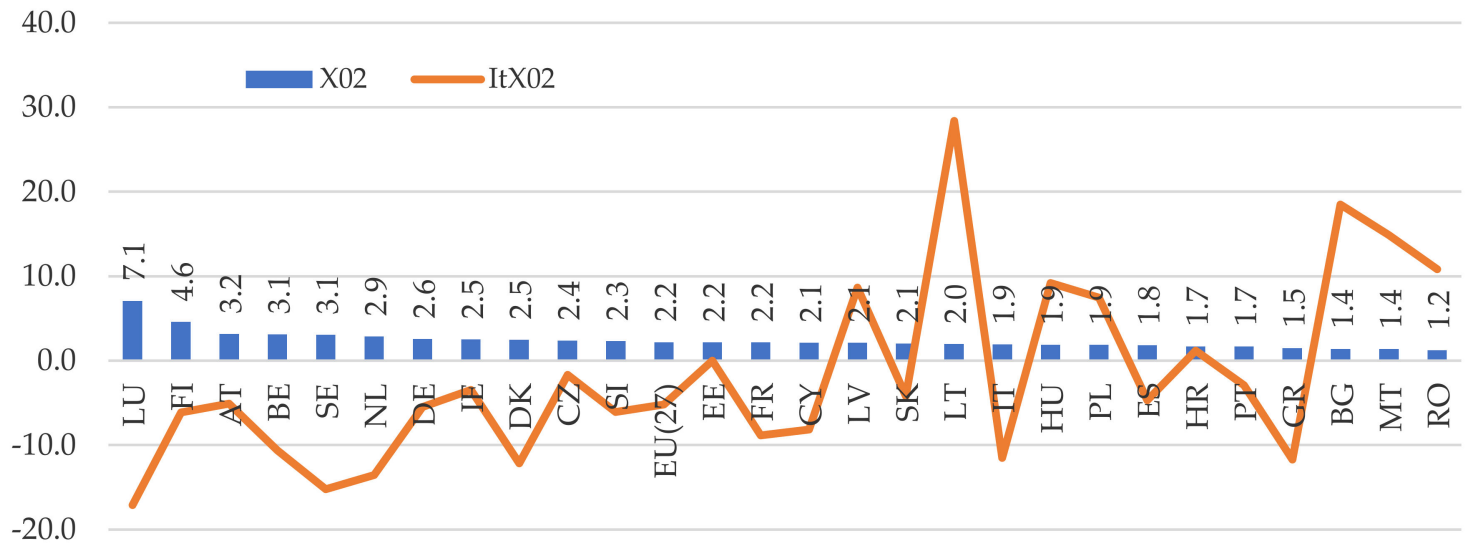

Figure 2. A ranking of EU (27) countries according to their final energy consumption in tonnes of oil equivalent per inhabitant $\left(\mathrm{X}_{02}\right)$ in 2019 and index $\mathrm{I}_{\mathrm{tX} 02}$ for 2019 (2010 = 100); Source: own work based on [76].

The highest final energy consumption among the EU (27) countries is recorded in the transport sector (in $2019 \mathrm{X}_{04}=0.65$ ), followed by a slightly lower consumption in the industrial sector $\left(X_{03}=0.53\right)$ and in the households sector $\left(X_{06}=0.55\right)$ and the lowest but also significant consumption in the commercial and public services sector $\left(X_{05}=0.29\right)$. Malta has the lowest final energy consumption in the industrial and households sector $\left(\mathrm{X}_{03}=0.11 ; \mathrm{X}_{06}=0.20\right.$, respectively) and Romania-in the transport and commercial and public services sector $\left(X_{04}=0.34 ; X_{05}=0.10\right)$. Conversely, at the other extreme, the topranked country consuming the most final energy in the last decade in the industrial and households sector is Finland $\left(\mathrm{X}_{03}=1.98 ; \mathrm{X}_{06}=1.02\right.$, respectively $)$ and in the transport and commercial and public services sector-Luxembourg $\left(X_{04}=3.51 ; X_{05}=0.86\right)$. As mentioned earlier, since 2010, total primary and final energy consumption has decreased in the EU (27) countries, and this has been facilitated by decreasing energy consumption in the industrial $\left(\mathrm{I}_{\mathrm{t} \times 03}=-3.6\right)$, households $\left(\mathrm{I}_{\mathrm{t} \times 06}=-12.9\right)$ and commercial and public services $\left(\mathrm{I}_{\mathrm{t} \times 05}=-9.0\right)$ sector. Energy consumption in the transport sector has increased $\left(\mathrm{I}_{\mathrm{t} X 04}=1.9\right)$, with Bulgaria, Lithuania, Hungary, Poland and Romania being the main contributors to this increase. The EU (27) countries vary significantly in final energy consumption by sector, which is confirmed by the calculated coefficients of variation $V_{s}, D$ and $R$. The largest variation between EU (27) countries is found in final energy consumption in the transport and industrial sector and the smallest—in the households sector (Table 3).

On average, in the EU (27), the share of total renewable energy in gross final energy consumption in 2019 was $X_{07}=19.7 \%$. The EU (27) Member States with the highest share of renewable energy in 2019 were Sweden $\left(X_{07}=56.4 \%\right)$, Finland $\left(X_{07}=43.1 \%\right)$ and Latvia $\left(X_{07}=41.0 \%\right)$. Shares above 30 per cent were also reported in countries such as Denmark, Austria, Estonia and Portugal. In turn, the smallest share of total renewable energy in gross final energy consumption in 2019 was reported in countries such as Luxembourg $\left(X_{07}=7.0 \%\right)$, Malta $\left(X_{07}=8.5 \%\right)$, the Netherlands $\left(X_{07}=8.8 \%\right)$ and Belgium $\left(X_{07}=9.9 \%\right)$. A considerable increase in the share of renewable energy in final energy consumption was observed in all EU (27) countries (except Hungary) (on average for all EU (27) countries $\mathrm{I}_{\mathrm{t} X 07}=36.8 \%$ ). Between 2010 and 2019, an exceptionally high, almost eightfold increase of this indicator was observed in Malta $\left(\mathrm{I}_{\mathrm{t}}=767.0 \%\right)$, in addition to much smaller increases in countries such as Denmark, Ireland, Cyprus, Luxembourg, the Netherlands, Slovakia and Greece (Figure 3). 
Table 3. Final energy consumption in the industrial $\left(\mathrm{X}_{03}\right)$, transport $\left(\mathrm{X}_{04}\right)$, commercial and public services $\left(\mathrm{X}_{05}\right)$ and households $\left(\mathrm{X}_{06}\right)$ sector in EU (27) countries in 2010-2019—statistics.

\begin{tabular}{|c|c|c|c|c|c|c|c|}
\hline \multicolumn{2}{|c|}{ Statistics for } & EU (27) & $\begin{array}{c}\text { Country } \\
\text { Min Values }\end{array}$ & $\begin{array}{c}\text { Country } \\
\text { Max Values }\end{array}$ & $\mathbf{V}_{\mathbf{s}}$ & D & $\mathbf{R}$ \\
\hline \multirow{6}{*}{$\begin{array}{l}\text { Final energy } \\
\text { consumption in } \\
\text { the industrial } \\
\text { sector } \mathrm{X}_{03}\end{array}$} & 2010 & 0.55 & $0.11(\mathrm{MT})$ & $2.00(\mathrm{FI})$ & 70.7 & 18.8 & 1.9 \\
\hline & 2015 & 0.53 & $0.13(\mathrm{MT})$ & $1.87(\mathrm{FI})$ & 65.4 & 14.9 & 1.7 \\
\hline & 2016 & 0.53 & $0.12(\mathrm{MT})$ & $1.92(\mathrm{FI})$ & 66.7 & 15.7 & 1.8 \\
\hline & 2017 & 0.54 & $0.12(\mathrm{MT})$ & $1.94(\mathrm{FI})$ & 64.5 & 15.7 & 1.8 \\
\hline & 2018 & 0.54 & $0.12(\mathrm{MT})$ & $2.02(\mathrm{FI})$ & 64.9 & 17.3 & 1.9 \\
\hline & 2019 & 0.53 & $0.11(\mathrm{MT})$ & $1.98(\mathrm{FI})$ & 64.4 & 17.9 & 1.9 \\
\hline \multicolumn{2}{|c|}{$\mathrm{I}_{\mathrm{t} \times 03} 2019(2010=100)$} & -3.6 & 3.9 & -1.3 & - & - & - \\
\hline \multirow{6}{*}{$\begin{array}{l}\text { Final energy } \\
\text { consumption in } \\
\text { the transport } \\
\text { sector } \mathrm{X}_{04}\end{array}$} & 2010 & 0.64 & $0.24(\mathrm{RO})$ & 4.33 (LU) & 95.2 & 17.7 & 4.1 \\
\hline & 2015 & 0.62 & $0.27(\mathrm{RO})$ & 3.48 (LU) & 80.1 & 13.0 & 3.2 \\
\hline & 2016 & 0.63 & $0.29(\mathrm{RO})$ & 3.31 (LU) & 74.4 & 11.4 & 3.0 \\
\hline & 2017 & 0.64 & $0.31(\mathrm{RO})$ & 3.33 (LU) & 72.7 & 10.6 & 3.0 \\
\hline & 2018 & 0.64 & $0.32(\mathrm{RO})$ & 3.49 (LU) & 74.9 & 10.8 & 3.2 \\
\hline & 2019 & 0.65 & $0.34(\mathrm{RO})$ & 3.51 (LU) & 74.4 & 10.4 & 3.2 \\
\hline \multicolumn{2}{|c|}{$\mathrm{I}_{\mathrm{t} X 04} 2019(2010=100)$} & 1.9 & 38.3 & $-19.1(\mathrm{LU})$ & - & - & - \\
\hline \multirow{6}{*}{$\begin{array}{l}\text { Final energy } \\
\text { consumption in } \\
\text { the commercial } \\
\text { and public services } \\
\text { sector } \mathrm{X}_{05}\end{array}$} & 2010 & 0.32 & $0.09(\mathrm{RO})$ & 0.84 (LU) & 47.9 & 9.1 & 0.8 \\
\hline & 2015 & 0.29 & $0.09(\mathrm{RO})$ & 0.70 (LU) & 42.3 & 8.0 & 0.6 \\
\hline & 2016 & 0.30 & $0.09(\mathrm{RO})$ & 0.69 (LU) & 40.9 & 7.6 & 0.6 \\
\hline & 2017 & 0.30 & $0.09(\mathrm{RO})$ & 0.77 (LU) & 42.3 & 8.1 & 0.7 \\
\hline & 2018 & 0.30 & $0.10(\mathrm{RO})$ & 0.79 (LU) & 43.3 & 7.9 & 0.7 \\
\hline & 2019 & 0.29 & $0.10(\mathrm{RO})$ & $0.86(\mathrm{LU})$ & 46.6 & 8.6 & 0.8 \\
\hline \multicolumn{2}{|c|}{$\mathrm{I}_{\mathrm{t} X 05} 2019(2010=100)$} & -9.00 & 9.10 & 2.40 & - & - & - \\
\hline \multirow{5}{*}{$\begin{array}{l}\text { Final energy } \\
\text { consumption in } \\
\text { the households } \\
\text { sector } \mathrm{X}_{06}\end{array}$} & 2010 & 0.63 & $0.17(\mathrm{MT})$ & $1.09(\mathrm{FI})$ & 36.8 & 6.5 & 0.9 \\
\hline & 2016 & 0.57 & $0.17(\mathrm{MT})$ & $0.97(\mathrm{FI})$ & 34.8 & 5.7 & 0.8 \\
\hline & 2017 & 0.57 & $0.20(\mathrm{MT})$ & $1.05(\mathrm{FI})$ & 34.5 & 5.3 & 0.8 \\
\hline & 2018 & 0.55 & $0.20(\mathrm{MT})$ & $1.03(\mathrm{FI})$ & 33.9 & 5.3 & 0.8 \\
\hline & 2019 & 0.55 & $0.20(\mathrm{MT})$ & $1.02(\mathrm{FI})$ & 32.4 & 5.0 & 0.8 \\
\hline \multicolumn{2}{|c|}{$\mathrm{I}_{\mathrm{t} X 06} 2019(2010=100)$} & -12.9 & 22.5 & -6.0 & - & - & - \\
\hline
\end{tabular}

Key: $X_{\min }-$ minimum value for the country, $X_{\max }$-maximum value for the country, $\mathrm{V}_{\mathrm{s}}$-coefficient of variation in \% for EU (27) countries, $\mathrm{D}$-distance $(\mathrm{max} / \mathrm{min}), \mathrm{R}$-range $(\max -\min ), \mathrm{I}_{\mathrm{t}}$-fixed-base index $\mathrm{I}_{\mathrm{t}} 2019(2010=100)$ in \%. Source: own work based on [76].

In the EU (27), the share of renewable energy sources in transport in 2019 was at $8.9 \%$ and increased since 2010 by $\mathrm{I}_{\mathrm{t} \times 08}=61.8$ p.p. The share of renewable energy sources in this sector is lowest in countries such as Cyprus, Croatia and Estonia, and highest in recent years in Sweden, and previously in Finland and Austria. The share of renewable sources of electricity in the EU (27) on average is much higher than in transport and was equal to $\mathrm{X}_{09}=34.1 \%$ in 2019. Like the transport sector, the share of renewable sources of electricity has also increased by 60 percentage points. Over the last decade, this increase has been most notable in Malta, where the value of this indicator was at its lowest for years. By contrast, in Austria, which is at the other extreme, where the share of renewable sources of electricity has remained above $70 \%$ for years, there has only been a 13 percentage point increase. The share of renewable energy sources in heating and cooling in EU (27) countries has exceeded $20 \%$ in recent years (in $2019 \mathrm{X}_{10}=22.1 \%$ ). In this case, there has been an increase of 30 p.p. compared to $2010\left(\mathrm{I}_{\mathrm{t}}\right)$. The lowest value of this indicator is recorded in 
the Netherlands, at less than $5-7 \%$, and the highest in Sweden where the share exceeds $60 \%$ (in $2019 X_{10}=66.1 \%$ ). As both Austria and Sweden are the countries with the highest share of renewable energy sources, only a slight increase of this indicator in recent past was observed there. In addition, the EU (27) countries are significantly varied in terms of the share of renewable energy sources. This variation has been only slightly reduced, which means that there is still a significant distance between countries with very high and very low shares of renewable energy sources (Table 4).

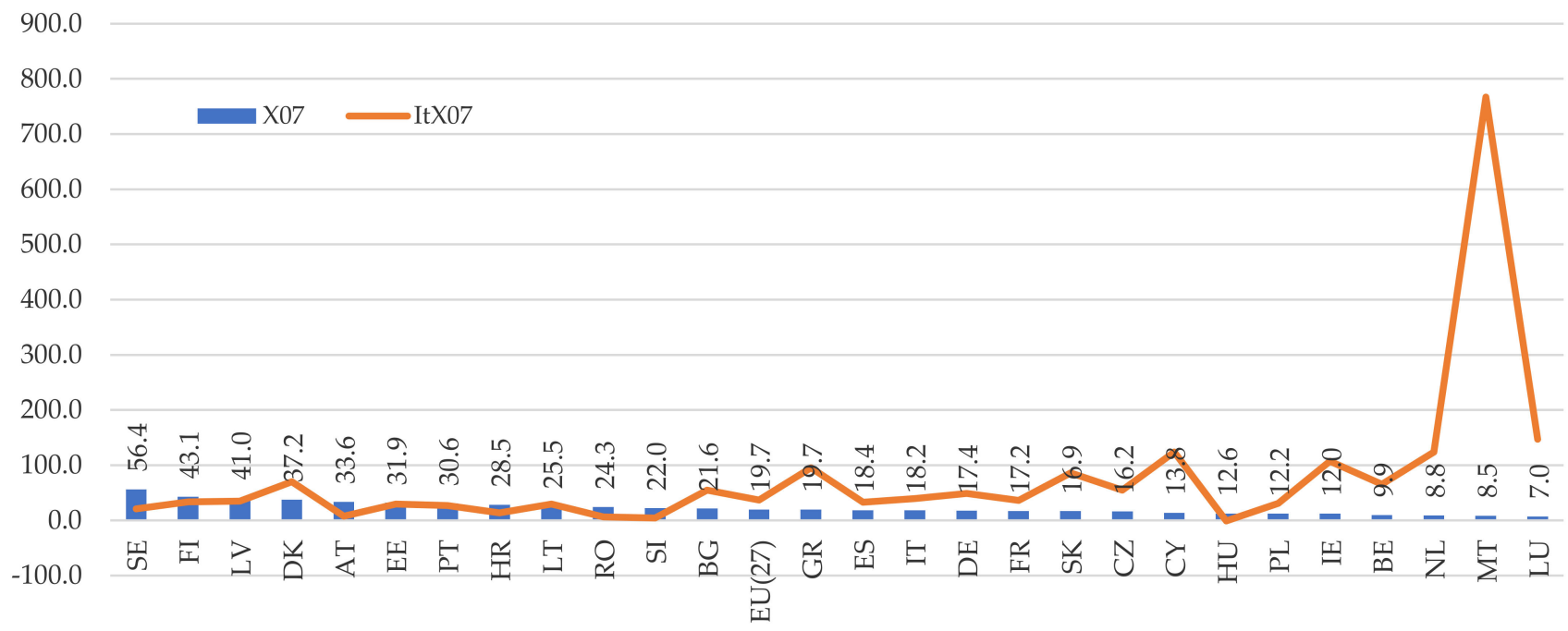

Figure 3. A ranking of EU (27) countries according to the share of total renewable energy in gross final energy consumption in \% (X07). in 2019 and index $\mathrm{I}_{\mathrm{t} X 07}$ for $2019(2010=100)$. Source: own work based on [76].

Table 4. The share of renewable energy sources in transport $\left(X_{08}\right)$, renewable sources of electricity $\left(X_{09}\right)$ as well as renewable energy sources in heating and cooling $\left(\mathrm{X}_{10}\right)$ in EU (27) countries in 2010-2019-statistics.

\begin{tabular}{|c|c|c|c|c|c|c|c|}
\hline \multicolumn{2}{|c|}{ Statistics for } & \multirow{2}{*}{$\begin{array}{c}\text { EU (27) } \\
5.5\end{array}$} & \multirow{2}{*}{$\begin{array}{c}\begin{array}{c}\text { Country } \\
\text { Min Values }\end{array} \\
0.0(\mathrm{MT})\end{array}$} & \multirow{2}{*}{$\begin{array}{c}\begin{array}{c}\text { Country } \\
\text { Max Values }\end{array} \\
10.7(\mathrm{AT})\end{array}$} & \multirow{2}{*}{$\begin{array}{l}\mathrm{V}_{\mathbf{s}} \\
65.3\end{array}$} & \multirow{2}{*}{$\begin{array}{l}\text { D } \\
-\end{array}$} & \multirow{2}{*}{$\begin{array}{c}\mathbf{R} \\
10.7\end{array}$} \\
\hline \multirow{6}{*}{$\begin{array}{l}\text { Share of renewable } \\
\text { energy sources in } \\
\text { transport } \mathrm{X}_{08}\end{array}$} & 2010 & & & & & & \\
\hline & 2015 & 6.8 & $0.4(\mathrm{EE})$ & $24.8(\mathrm{FI})$ & 82.3 & 60.0 & 24.4 \\
\hline & 2016 & 7.2 & $0.4(\mathrm{EE})$ & 26.6 (SE) & 76.8 & 61.6 & 26.1 \\
\hline & 2017 & 7.5 & $0.4(\mathrm{EE})$ & 26.8(SE) & 75.0 & 64.4 & 26.4 \\
\hline & 2018 & 8.3 & $2.6(\mathrm{HR})$ & 29.7 (SE) & 67.0 & 11.5 & 27.1 \\
\hline & 2019 & 8.9 & $3.3(\mathrm{CY})$ & 30.3 (SE) & 61.8 & 9.1 & 27.0 \\
\hline \multicolumn{2}{|c|}{$\mathrm{I}_{\mathrm{t} \times 08} 2019(2010=100)$} & 61.8 & - & - & - & - & - \\
\hline \multirow{6}{*}{$\begin{array}{c}\text { Share of renewable } \\
\text { sources of electricity } X_{09}\end{array}$} & 2010 & 21.3 & $0.0(\mathrm{MT})$ & 66.4 (AT) & 80.3 & 2073.7 & 66.3 \\
\hline & 2015 & 29.7 & $4.3(\mathrm{MT})$ & 71.5 (AT) & 65.3 & 16.6 & 67.2 \\
\hline & 2016 & 30.2 & $5.7(\mathrm{MT})$ & 72.5 (AT) & 64.4 & 12.7 & 66.8 \\
\hline & 2017 & 31.1 & $6.8(\mathrm{MT})$ & 71.6 (AT) & 63.0 & 10.5 & 64.8 \\
\hline & 2018 & 32.2 & 7.7 (MT) & 74.2 (AT) & 60.9 & 9.7 & 66.5 \\
\hline & 2019 & 34.1 & 8.0 (MT) & 75.1 (AT) & 58.9 & 9.3 & 67.1 \\
\hline
\end{tabular}


Table 4. Cont.

\begin{tabular}{|c|c|c|c|c|c|c|c|}
\hline \multicolumn{2}{|c|}{ Statistics for } & EU (27) & $\begin{array}{c}\text { Country } \\
\text { Min Values }\end{array}$ & $\begin{array}{c}\text { Country } \\
\text { Max Values }\end{array}$ & $\mathbf{V}_{\mathrm{s}}$ & D & $\mathbf{R}$ \\
\hline \multicolumn{2}{|c|}{$\mathrm{I}_{\mathrm{t} X 09} 2019(2010=100)$} & 60.0 & $25,021.9$ & 13.2 & - & - & - \\
\hline \multirow{6}{*}{$\begin{array}{l}\text { Share of renewable } \\
\text { energy sources in } \\
\text { heating and cooling } X_{10}\end{array}$} & 2010 & 17.0 & $3.1(\mathrm{NL})$ & 58.5 (SE) & 64.3 & 18.9 & 55.4 \\
\hline & 2015 & 20.3 & $5.2(\mathrm{NL})$ & $65.3(\mathrm{SE})$ & 60.1 & 12.5 & 60.1 \\
\hline & 2016 & 20.5 & $5.1(\mathrm{NL})$ & 65.5 (SE) & 60.0 & 12.8 & 60.3 \\
\hline & 2017 & 20.9 & $5.7(\mathrm{NL})$ & $65.8(\mathrm{SE})$ & 59.5 & 11.6 & 60.1 \\
\hline & 2018 & 21.2 & $6.1(\mathrm{NL})$ & $65.3(\mathrm{SE})$ & 58.1 & 10.8 & 59.3 \\
\hline & 2019 & 22.1 & 7.1 (NL) & 66.1 (SE) & 55.9 & 10.5 & 59.8 \\
\hline \multicolumn{2}{|c|}{$\mathrm{I}_{\mathrm{t} \times 10} 2019(2010=100)$} & 29.8 & 128.4 & 13.1 & - & - & - \\
\hline
\end{tabular}

Key: $X_{\min }-$ minimum value for the country, $X_{\max }-$ maximum value for the country, $\mathrm{V}_{\mathrm{s}}$-coefficient of variation in \% for EU (27) countries, $\mathrm{D}$-distance $(\max / \mathrm{min}), \mathrm{R}$-range $(\max -\min ), \mathrm{I}_{\mathrm{t}}$-fixed-base index $\mathrm{I}_{\mathrm{t}} 2019(2010=100)$ in \%. Source: own work based on [76].

The use of energy by the economy and the population has negative consequences in the form of greenhouse gas emissions. As the collected data shows, the average share of greenhouse gas emissions from energy as a \% of total emissions $\left(\mathrm{X}_{11}\right)$ for EU (27) countries decreased slightly compared to $2010\left(\mathrm{I}_{\mathrm{t} \times 11}=-2.7\right.$ p.p. $)$ and amounted to $74.7 \%$ in 2018. The largest decreases in greenhouse gas emissions from energy between 2010 and 2018 were seen in countries such as Malta ( -27.9 percentage points), Greece $(-11.1)$, Denmark (-11.0), Ireland (-10.7). On the other hand, increases were recorded in countries such as Estonia ( +1.4 percentage points) and Poland $(+0.1)$. Evidently, these countries have a very serious problem with rational energy management because not only are they at the top of the ranking of countries according to greenhouse gas emissions in the EU (27) (for Poland $\mathrm{X}_{11}=82.3 \%$ and for Estonia $\mathrm{X}_{11}=87.1 \%$ ) but also they are the only countries among the twenty EU Member States that have not reduced their emissions of greenhouse gases from energy in the last decade but instead their emissions have actually grown. The countries with the lowest greenhouse gas emissions from energy in the EU (27) are Ireland $\left(X_{11}=56.9 \%\right)$, Lithuania $\left(X_{11}=57.7 \%\right)$ and Malta $\left(X_{11}=57.8 \%\right)($ Figure 4$)$.

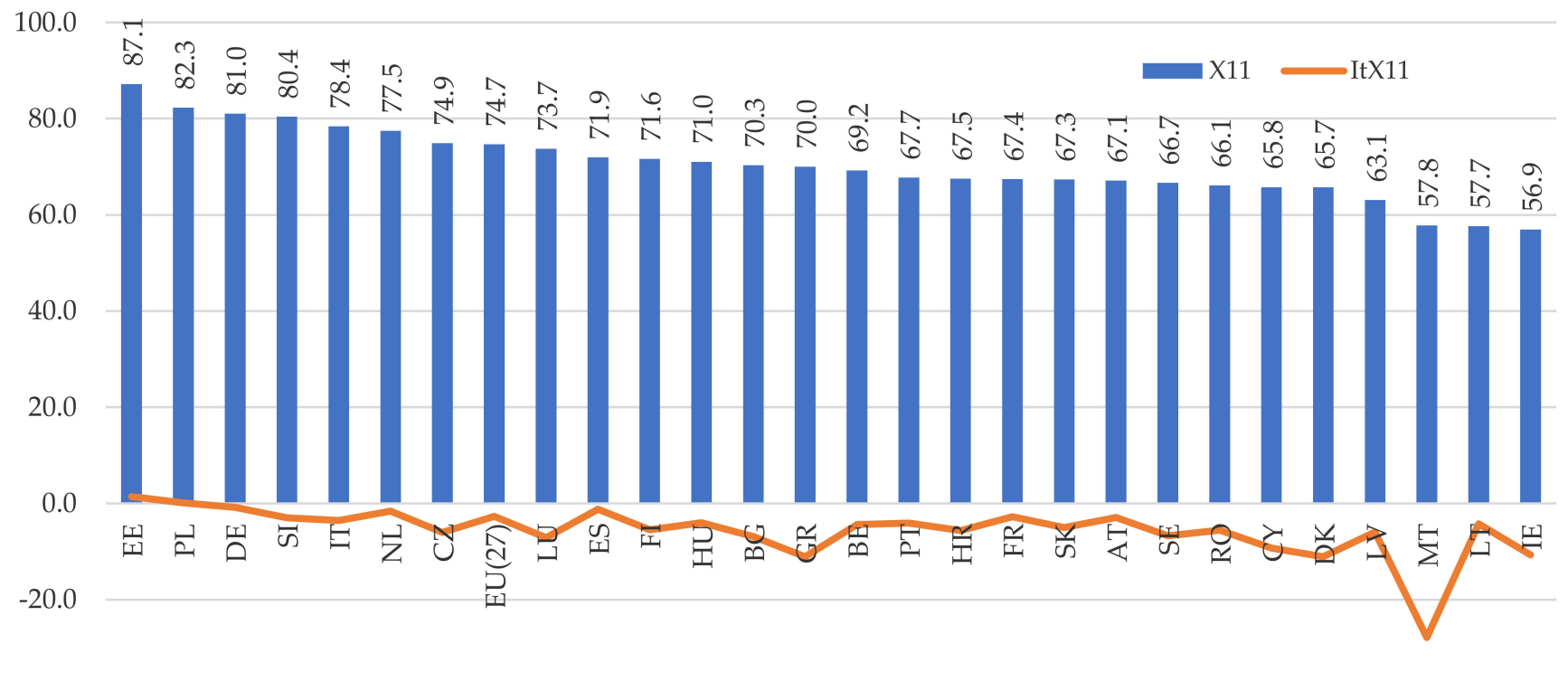

$-40.0$

Figure 4. A ranking of EU (27) countries according to greenhouse gas emissions from energy $\left(\mathrm{X}_{11}\right)$ in 2019 and index $\mathrm{I}_{\mathrm{t} X 11}$ for $2019(2010=100)$. Source: own work based on [76]. 
One of the objectives of the paper was to examine whether the level of energy consumption in total and by individual sectors of the economy is related to the methods of energy generation, economic development of the countries and environmental impacts in the form of greenhouse gas emissions. On the basis of the analyses performed, it can be concluded that there is a significant positive correlation between all of the indicators characterising primary $\left(\mathrm{X}_{01}\right)$ and final energy consumption $\left(\mathrm{X}_{02}\right)$ and consumption by individual sectors: industry $\left(\mathrm{X}_{03}\right)$, transport $\left(\mathrm{X}_{04}\right)$, commercial and public services $\left(\mathrm{X}_{05}\right)$ and households $\left(\mathrm{X}_{06}\right)$. Thus, it can be unambiguously stated that there is a noticeable distance and significant differences in the levels of these indicators between the EU (27) countries with high and low energy consumption in total and by individual sectors. In other words, the same countries consume the most (e.g., Luxembourg, Finland, Belgium, Sweden, Austria) and the least (e.g., Romania, Malta, Bulgaria, Greece, Croatia) amount of energy in total and in individual sectors of the economy. In addition, the analyses revealed significant positive correlations between indicators characterising the share of renewable energy in total $\left(\mathrm{X}_{07}\right)$ and in transport $\left(\mathrm{X}_{08}\right)$, electricity $\left(\mathrm{X}_{09}\right)$ and heating and cooling $\left(\mathrm{X}_{10}\right)$. This allows the conclusion that in countries having a considerable share of renewable energy sources in transport, the share is also relatively higher in electricity and heating and cooling. By contrast, in countries at the other extreme with the lowest share of renewable energy, all values of these indicators are significantly lower in all sectors of the economy (Table 5).

Table 5. Correlations $r_{x y}$ between variables characterising primary and final energy consumption in total and by individual sectors of the economy $\left(\mathrm{X}_{01}, \mathrm{X}_{02}, \mathrm{X}_{03}, \mathrm{X}_{04}, \mathrm{X}_{05}, \mathrm{X}_{06}\right)$ as well as the share of renewable energy in final energy consumption in total and by sector $\left(X_{07}, X_{08}, X_{08}, X_{10}\right)$ in EU (27) countries in 2019.

\begin{tabular}{cccccccccccc}
\hline Variable & $\mathbf{X}_{\mathbf{0 1}}$ & $\mathbf{X}_{\mathbf{0 2}}$ & $\mathbf{X}_{\mathbf{0 3}}$ & $\mathbf{X}_{\mathbf{0 4}}$ & $\mathbf{X}_{\mathbf{0 5}}$ & $\mathbf{X}_{\mathbf{0 6}}$ & $\mathbf{X}_{\mathbf{0 7}}$ & $\mathbf{X}_{\mathbf{0 8}}$ & $\mathbf{X}_{\mathbf{0 9}}$ & $\mathbf{X}_{\mathbf{1 0}}$ \\
\hline $\mathbf{X}_{\mathbf{0 1}}$ & 1.000 & $0.949^{*}$ & $0.793^{*}$ & $0.741^{*}$ & $0.917^{*}$ & $0.720^{*}$ & 0.063 & $0.436^{*}$ & -0.064 & -0.039 \\
\hline $\mathbf{X}_{\mathbf{0 2}}$ & $0.949^{*}$ & 1.000 & $0.721^{*}$ & $0.866^{*}$ & $0.953^{*}$ & $0.669^{*}$ & 0.014 & 0.323 & -0.022 & -0.085 \\
\hline $\mathbf{X}_{\mathbf{0 3}}$ & $0.793^{*}$ & 0.721 & 1.000 & 0.319 & $0.620^{*}$ & $0.737^{*}$ & 0.341 & $0.681^{*}$ & 0.186 & 0.167 \\
\hline $\mathbf{X}_{\mathbf{0 4}}$ & $0.741^{*}$ & $0.866^{*}$ & 0.319 & 1.000 & $0.827^{*}$ & 0.319 & -0.214 & -0.013 & -0.156 & -0.230 \\
\hline $\mathbf{X}_{\mathbf{0 5}}$ & $0.917^{*}$ & $0.953^{*}$ & $0.620^{*}$ & $0.827^{*}$ & 1.000 & $0.616^{*}$ & -0.031 & 0.305 & -0.100 & -0.083 \\
\hline $\mathbf{X}_{\mathbf{0 6}}$ & $0.720^{*}$ & $0.669^{*}$ & $0.737^{*}$ & 0.319 & $0.616^{*}$ & 1.000 & $0.403 *$ & $0.402 *$ & 0.276 & 0.233 \\
\hline $\mathbf{X}_{\mathbf{0 7}}$ & 0.063 & 0.014 & 0.341 & -0.214 & -0.031 & $0.403^{*}$ & 1.000 & $0.554^{*}$ & $0.779 *$ & $0.903 *$ \\
\hline $\mathbf{X}_{\mathbf{0 8}}$ & $0.436^{*}$ & 0.323 & $0.681 *$ & -0.013 & 0.305 & $0.402 *$ & $0.554^{*}$ & 1.000 & $0.396^{*}$ & 0.357 \\
\hline $\mathbf{X}_{\mathbf{0 9}}$ & -0.064 & -0.022 & 0.186 & -0.156 & -0.100 & 0.276 & $0.779 *$ & $0.396^{*}$ & 1.000 & $0.513 *$ \\
\hline $\mathbf{X}_{\mathbf{1 0}}$ & -0.039 & -0.085 & 0.167 & -0.230 & -0.083 & 0.233 & $0.903 *$ & 0.357 & $0.513 *$ & 1.000 \\
\hline
\end{tabular}

* The correlation coefficients marked by an asterisk are significant with $p<0.05 ; n=27$ (missing data was deleted on a case-to-case basis); Source: own work based on [76].

As shown in the regression and correlation analyses (Table 6, Table 7, Figure 5 between the total primary and final energy consumption and final energy consumption by individual sectors (industry, transport, commercial and public services and households) and economic development measured by GDP per capita $\left(\mathrm{X}_{12}\right)$, there is a significant positive correlation, which means that with the economic growth of the EU countries (27), the consumption of electricity increases significantly. The impact of economic development on energy consumption was confirmed by the $r_{\mathrm{xy}}$ correlation coefficients of value: $r_{\mathrm{X} 01 \times 12}=0.734$, $\mathrm{r}_{\mathrm{X} 02 \times 12}=0.806, \mathrm{r}_{\mathrm{X} 03 \times 12}=0.460, \mathrm{r}_{\mathrm{X} 04 \times 12}=0.732, \mathrm{r}_{\mathbf{X} 05 \times 12}=0.839, \mathrm{r}_{\mathrm{X} 06 \times 12}=0.508$ (Table 6). 
Table 6. Summary of multiple regression between variable $\mathrm{X}_{12}$ (GDP per capita) and variables $\mathrm{X}_{01}-\mathrm{X}_{06}$ describing primary and final energy consumption in total and by individual sectors-analysis of the impact of economic conditions on energy consumption in EU (27) countries in 2019.

\begin{tabular}{|c|c|c|c|c|c|c|}
\hline Statistic & X01 & X02 & X03 & X04 & X05 & X06 \\
\hline$r_{x y}$ & $0.734^{*}$ & $0.806^{*}$ & 0.460 * & $0.732 *$ & $0.839 *$ & $0.508^{*}$ \\
\hline $\mathrm{R}^{2}$ & 0.538 & 0.650 & 0.211 & 0.535 & 0.704 & 0.258 \\
\hline corrected $\mathrm{R}^{2}$ & 0.520 & 0.636 & 0.180 & 0.517 & 0.693 & 0.228 \\
\hline $\mathrm{F}(1.25)$ & 29.170 & 46.502 & 6.697 & 28.786 & 59.555 & 8.679 \\
\hline$p$ & 0.000 & 0.000 & 0.016 & 0.000 & 0.000 & 0.007 \\
\hline SEE & 0.848 & 0.703 & 0.332 & 0.394 & 0.080 & 0.159 \\
\hline
\end{tabular}

Key: $\mathrm{r}_{\mathrm{xy}}$-linear correlation coefficient; $\mathrm{R}^{2}$ —coefficient of determination; $\mathrm{F}$-F statistics; $p$-critical significance level; SEE-Standard Error of Estimation; * The correlation coefficients marked by an asterisk are significant with $p<0.05 ; n=27$ (missing data was deleted on a case-to-case basis); Source: own work based on [76].

Table 7. Correlations of energy consumption (variables $X_{01}-X_{06}$ ) and renewable sources of energy (variables $X_{07}-X_{10}$ ) with environmental impacts in the form of greenhouses gas emissions from energy $\left(X_{11}\right)$ and economic conditions $\left(X_{12}\right)$ in EU (27) countries in 2019.

\begin{tabular}{ccccccccccc}
\hline Variable & $\mathbf{X}_{\mathbf{0 1}}$ & $\mathbf{X}_{\mathbf{0 2}}$ & $\mathbf{X}_{\mathbf{0 3}}$ & $\mathbf{X}_{\mathbf{0 4}}$ & $\mathbf{X}_{\mathbf{0 5}}$ & $\mathbf{X}_{\mathbf{0 6}}$ & $\mathbf{X}_{\mathbf{0 7}}$ & $\mathbf{X}_{\mathbf{0 8}}$ & $\mathbf{X}_{\mathbf{0 9}}$ & $\mathbf{X}_{\mathbf{1 0}}$ \\
\hline$X_{11}$ & 0.263 & 0.143 & 0.162 & 0.086 & 0.124 & 0.219 & -0.114 & -0.025 & -0.178 & -0.164 \\
\hline$X_{12}$ & $0.734^{*}$ & $0.806^{*}$ & $0.460^{*}$ & $0.732^{*}$ & $0.839^{*}$ & $0.508^{*}$ & -0.077 & 0.321 & 0.131 & -0.252 \\
\hline
\end{tabular}

* The correlation coefficients marked by an asterisk are significant with $p<0.05 ; n=27$ (missing data was deleted on a case-to-case basis). Source: own work based on [76].

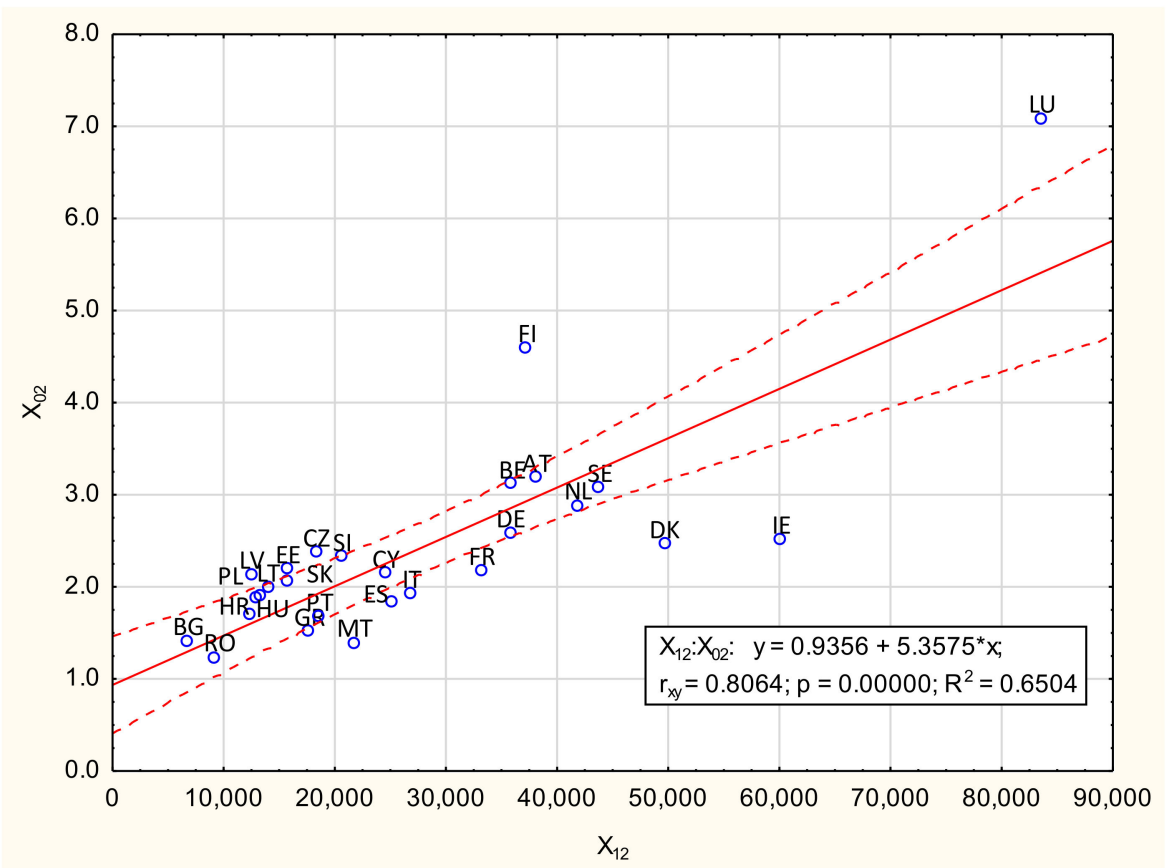

Figure 5. Correlation between final energy consumption and GDP per capita in EU (27) countries in 2019 (scatterplot for variables $X_{02}$ and $X_{12}$ ). Key: $r_{x y}$-linear correlation coefficient; $R^{2}$ —coefficient of determination. Source: own work based on [76].

However, it should be noted that the values of correlation $r_{x y}$ between variable $X_{12}$ and variables $\mathrm{X}_{01}, \mathrm{X}_{02}, \mathrm{X}_{03}, \mathrm{X}_{04}, \mathrm{X}_{05}$ and $\mathrm{X}_{06}$, although significant and relatively high, do not fully explain the impact of a country's GDP per capita on energy consumption. For example, the coefficient of determination $\mathrm{R}^{2}=0.650$ calculated for the variables $\mathrm{X}_{02}$ and $\mathrm{X}_{12}$ indicates only 
a 65 per cent effect of the variation of GDP per capita $\left(X_{12}\right)$ on the variation of final energy consumption $\left(\mathrm{X}_{02}\right)$. Thus, it appears that there are other remaining causal sources (other than GDP) that had an additional 35 per cent impact on the level and regional variation of final energy consumption. Therefore, it is advisable to expand future research to include more explanatory variables other than $X_{12}$ and to transform the regression function for one explanatory variable into a multiple regression function with more variables that affect energy consumption variation in EU (27) countries (Table 6, Figure 5).

Table 7 shows that there is no significant correlation between the level of economic development of the countries $\left(X_{12}\right)$ and the share of renewable energy in total $\left(X_{07}\right)$ and in transport $\left(X_{08}\right)$, in electricity $\left(X_{09}\right)$ or in heating and cooling $\left(X_{10}\right)$. This leads to an unambiguous conclusion that the economic development of EU (27) countries and the amount of produced and consumed energy from renewable sources are unrelated. Based on the analyses performed, it has also been found that there is a positive (but too weak and therefore insignificant) correlation between greenhouse gas emissions from energy $\left(X_{11}\right)$ and energy consumption $\left(\mathrm{X}_{01}, \mathrm{X}_{02}, \mathrm{X}_{03}, \mathrm{X}_{04}, \mathrm{X}_{05}, \mathrm{X}_{06}\right)$, and a negative (but too weak and insignificant) correlation between greenhouse gas emissions from energy and the share of renewable energy $\left(X_{07}, X_{08}, X_{09}, X_{10}\right)$. It is therefore reasonable to make a balanced claim that environmental pollution through greenhouse gas emissions from energy by EU countries increases with increasing primary and final energy consumption and with decreasing share of renewable energy sources in gross final energy consumption (Table 7).

The countries with the highest primary energy consumption $\left(X_{01}\right)$ and final energy consumption $\left(\mathrm{X}_{02}\right)$ in 2019 saw the largest significant decrease in consumption of energy between 2010 and $2019\left(\mathrm{I}_{\mathrm{t} X 01}, \mathrm{I}_{\mathrm{t} X 02}\right)$. This has been confirmed by the calculated significant negative correlation coefficients $\mathrm{r}_{\mathrm{X} 01 \mathrm{It} X 01}=-0.473$ and $\mathrm{r}_{\mathrm{X} 02 \mathrm{It} X 02}=-0.493$. In individual sectors under study, such as industry, transport and public and commercial services, a negative correlation can also be observed between the decrease in energy consumption in 2010-2019 and the volume of this consumption; however, the value of the coefficient is too low and therefore the relationship is not significant. The value of the coefficient was only significant in the households sector, with $\mathrm{r}_{\mathrm{X} 06 \mathrm{ItX} 06}=-0.461$. This means that the largest decrease in energy consumption occurred in the last decade in the households sector in countries with the highest household energy consumption and, conversely, in countries with the lowest household energy consumption the decrease in energy consumption between 2010 and 2019 was relatively smaller (Table 8).

Table 8. Correlations of variables characterising energy consumption, means of energy consumption reduction and greenhouse gas emissions from energy in 2019 (variables $X_{01}-X_{11}$ ) and the index $I_{t}$ representing change of values of these variables in 2010-2019 $(2010=100)$ in EU (27) countries.

\begin{tabular}{ccccccccccccc}
\hline X Variables & $\mathrm{X}_{\mathbf{0 1}}$ & $\mathrm{X}_{\mathbf{0 2}}$ & $\mathrm{X}_{\mathbf{0 3}}$ & $\mathrm{X}_{\mathbf{0 4}}$ & $\mathrm{X}_{\mathbf{0 5}}$ & $\mathrm{X}_{\mathbf{0 6}}$ & $\mathrm{X}_{\mathbf{0 7}}$ & $\mathrm{X}_{\mathbf{0 8}}$ & $\mathrm{X}_{\mathbf{0 9}}$ & $\mathrm{X}_{\mathbf{1 0}}$ & $\mathrm{X}_{\mathbf{1 1}}$ \\
\hline $\begin{array}{c}\text { Fixed-base index } \mathrm{I}_{\mathrm{t}} \\
\text { representing change in } \\
2010-2019(2010=100)\end{array}$ & $\mathrm{I}_{\mathrm{t} \times 01}$ & $\mathrm{I}_{\mathrm{t} \times 02}$ & $\mathrm{I}_{\mathrm{t} \times 03}$ & $\mathrm{I}_{\mathrm{t} \times 04}$ & $\mathrm{I}_{\mathrm{t} \times 05}$ & $\mathrm{I}_{\mathrm{t} \times 06}$ & $\mathrm{I}_{\mathrm{t} \times 07}$ & $\mathrm{I}_{\mathrm{t} \times 08}$ & $\mathrm{I}_{\mathrm{t} \times 09}$ & $\mathrm{I}_{\mathrm{t} \times 10}$ & $\mathrm{I}_{\mathrm{t} \times 11}$ \\
\hline $\begin{array}{c}\text { coefficient of } \\
\begin{array}{c}\text { correlation } \mathrm{r}_{\mathrm{Xy}} \\
\text { between } \mathrm{X} \text { and } \mathrm{I}_{\mathrm{t}}\end{array}\end{array}$ & $-0.473^{*}$ & $-0.493^{*}$ & -0.169 & -0.333 & -0.126 & $-0.461 *$ & -0.352 & 0.056 & -0.265 & -0.228 & $0.626^{*}$ \\
\hline
\end{tabular}

* The correlation coefficients marked by an asterisk are significant with $p<0.05 ; n=27$ (missing data was deleted on a case-to-case basis). Source: own work based on [76].

The analyses performed also revealed a relationship, very important in terms of environmental impact of energy consumption, between greenhouse gas emissions from energy and their change (increase or decrease in the share of these emissions) between 2010 and 2018 in individual EU (27) countries. The significant positive correlation $r_{X 11 I X 11}=0.626$ suggests that countries that, in relative terms, emit the most greenhouse gases from energy have also reduced their emissions in the most limited way in the last decade or have even seen an increase in greenhouse gas emissions from energy (Table 8). This is a very undesirable phenomenon and these countries, especially Poland and Estonia, should take 
effective and efficient measures as soon as possible to reduce air pollution arising from energy consumption.

All values calculated for correlation between the analysed variables are negative (Table 9). Based on these calculations, positive conclusions can be drawn. Namely, the greatest decreases in primary and final energy consumption in total and in individual sectors in the EU (27) countries in the years 2010-2019 occurred significantly more often in countries with the highest consumption of energy.

Table 9. Correlations of variables characterising energy consumption and greenhouse gas emissions from energy in 2019 (variables $X_{01}-X_{11}$ ), and the index $I_{t}$ representing change of values of these variables in $2010-2019(2010=100)$ in EU (27) countries.

\begin{tabular}{|c|c|c|c|c|c|c|}
\hline Variable & $\mathrm{I}_{\mathrm{t} \times 01}$ & $\mathrm{I}_{\mathrm{t} \times 02}$ & $\mathrm{I}_{\mathrm{t} \times 03}$ & $\mathrm{I}_{\mathrm{t} \times 04}$ & $\mathbf{I}_{\mathbf{t} \times 05}$ & $I_{\text {tX06 }}$ \\
\hline \multicolumn{7}{|c|}{$\begin{array}{c}\text { Correlations of energy consumption in } 2019 \text { with change } I_{t} \text { of energy consumption in total and ir } \\
\text { individual sectors in } 2010-2019(2010=100)\end{array}$} \\
\hline $\mathrm{X}_{01}$ & $-0.473^{*}$ & $-0.546^{*}$ & -0.394 * & -0.483 * & -0.286 & $-0.456^{*}$ \\
\hline$x_{02}$ & $-0.443^{*}$ & -0.493 * & -0.354 & -0.451 * & -0.217 & -0.453 * \\
\hline $\mathrm{X}_{03}$ & -0.248 & $-0.383^{*}$ & -0.169 & -0.326 & -0.348 & -0.299 \\
\hline$X_{04}$ & -0.332 & -0.352 & -0.346 & -0.333 & -0.003 & -0.379 \\
\hline $\mathrm{X}_{05}$ & $-0.563 *$ & $-0.533^{*}$ & $-0.435^{*}$ & $-0.548^{*}$ & -0.126 & $-0.416^{*}$ \\
\hline$x_{06}$ & -0.323 & $-0.402 *$ & -0.133 & -0.254 & -0.450 * & $-0.461 *$ \\
\hline
\end{tabular}

Correlations of change $I_{t}$ of energy consumption in total and in individual sectors in 2010-2019 $(2010=100)$ with environmental impacts $\left(X_{11}\right)$ and economic conditions $\left(X_{12}\right)$ in 2019

\begin{tabular}{ccccccc}
\hline $\mathrm{X}_{11}$ & -0.206 & -0.317 & -0.248 & -0.139 & -0.260 & -0.365 \\
\hline $\mathrm{X}_{12}$ & $-0.634^{*}$ & $-0.639 *$ & $-0.418^{*}$ & $-0.625^{*}$ & -0.203 & $-0.569 *$ \\
\hline
\end{tabular}

${ }^{*}$ The correlation coefficients marked by an asterisk are significant with $p<0.05 ; n=27$ (missing data was deleted on a case-to-case basis). Source: own work based on [76].

This is a positive occurrence, particularly in terms of reducing energy consumption by the countries that consume the most energy. There is also a significant negative correlation of the change in energy consumption in total and by individual sectors with economic development of the countries. In this case, an unambiguous conclusion can be drawn that the decrease in energy consumption between 2010 and 2019 was more substantial in countries with higher levels of economic development. Conversely, in countries with lower levels of economic development, the decrease in consumption was negligible or even an increase in energy consumption was reported (Figure 6).

As can be deduced from the calculations (Table 9), no significant correlations have been shown between changes in energy consumption in 2010-2019 and the level of greenhouse gas emissions by EU (27) countries in 2019; however, the values are negative which also indicates stronger downward trends in energy consumption in countries with higher greenhouse gas emissions from energy. 


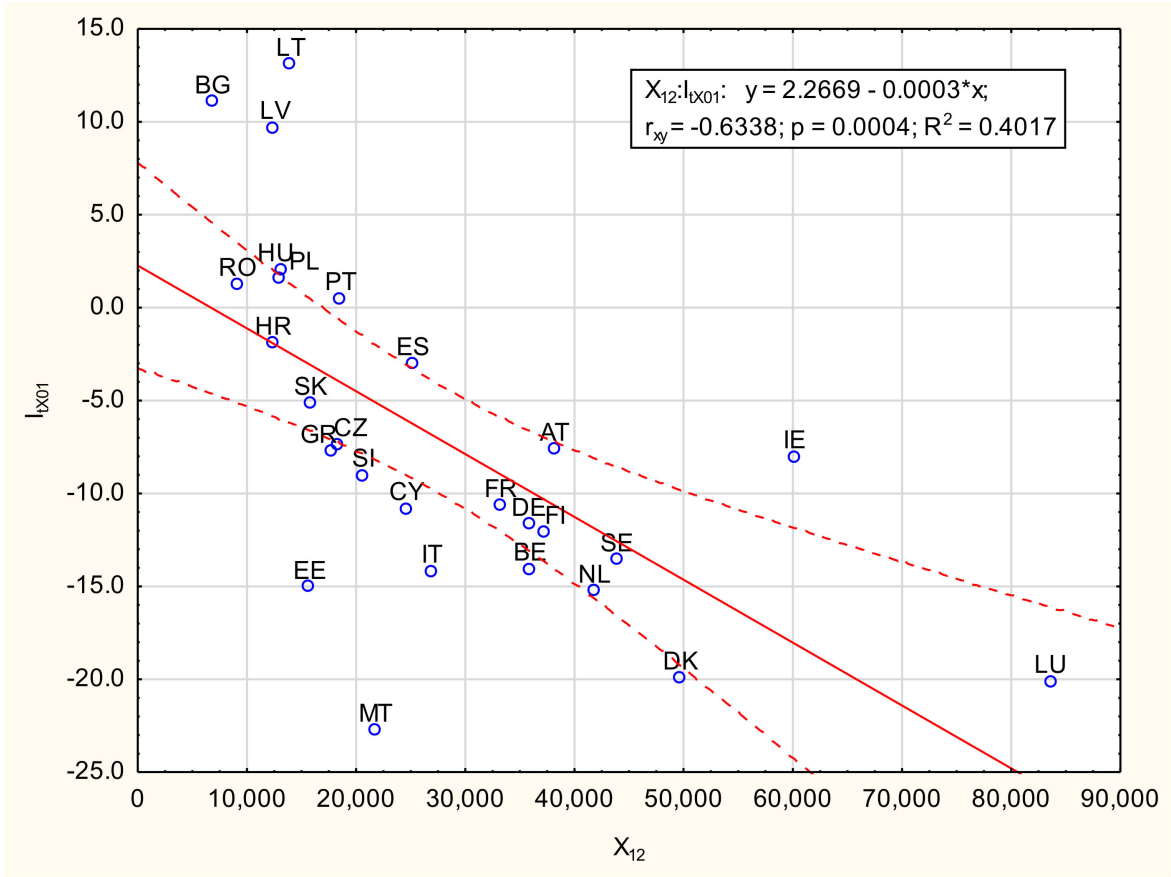

Figure 6. Correlation between change in primary energy consumption in 2010-2019 $\left(\mathrm{I}_{\mathrm{t} X 01}\right)$ and GDP per capita in EU (27) countries in 2019 (scatterplot for variables $I_{t X 01}$ and $X_{12}$ ). Key: $r_{x y}$-linear correlation coefficient; $\mathrm{R}^{2}$ —coefficient of determination. Source: own work based on [76].

\section{Discussion}

The literature includes a number of studies that focus on the causal links between economic growth, energy consumption and their impact on environmental pollution and indirectly on greenhouse gas emissions [2,11]. In this chapter, some research results in this area will be presented.

Odugbesan and Rjoub [2], Belaïd and Zrelli [4], Odabasi and Citlak [6], Radmehr et al. [10], Ossowska and Janiszewska [16], Omri and Belaïd [21], Acaravci and Ozturk [43], Ozcan et al. [48] and Loures and Ferreira [55] in their studies analysed trilateral links between economic growth, energy consumption and environmental pollution. As pointed out by Waheed et al. [49], it is this relationship between increasing carbon dioxide emissions, energy consumption and economic growth that is relevant from all perspectives, i.e., from the perspective of economic policy, total and sectoral energy consumption as well as national and global environmental planning.

Belaïd and Zrelli [4] examined the causal relationship between renewable and nonrenewable energy consumption, GDP and carbon dioxide emissions in nine Mediterranean countries over the period of 1980-2012. The findings of their study indicate existence of a short-term bidirectional relationship between GDP, renewable electricity consumption and $\mathrm{CO}_{2}$ emissions. The results of the study also confirmed the hypothesis of feedback between real GDP and renewable electricity consumption. However, in the long run, the study revealed the existence of a bidirectional relationship between non-renewable electricity consumption and carbon dioxide emissions as well as the absence of a causal relationship of $\mathrm{CO}_{2}$ emissions and non-renewable electricity consumption with real GDP.

Radmehr et al. [10] included spatial effects into their study on the nexus of these three variables. Their study, which focused on 21 EU countries over the period of 1995-2014, revealed a bidirectional link between economic growth and renewable energy consumption and between economic growth and carbon dioxide emissions. Furthermore, the study found a unidirectional link between renewable energy and carbon dioxide emissions. In addition, the results show that economic growth is more strongly spatially correlated compared to other variables. This means that EU countries are more linked to each other in economic conditions than in environmental issues, i.e., renewable energy consumption or carbon emissions. 
In the MINT countries (Mexico, Indonesia, Nigeria and Turkey), a study by Odugbesan and Rjoub [2] allowing for urbanisation in the study model found, inter alia, a long-run relationship from economic growth, energy consumption and $\mathrm{CO}_{2}$ emissions to urbanisation among all MINT countries.

Unlike other studies analysing the causal links between energy consumption, economic growth and environmental degradation, Ozcan et al. [48] used two complex indicators, i.e., "Ecological Footprint (EF) and Environmental Performance Index (EPI) reflecting different dimensions of environmental pollution" ([48], p. 204). In effect, they extended their investigation beyond air pollution to the problem of environmental pollution in general. They conducted their study covering 35 OECD countries and a study period of 2000-2014. Results from an analysis indicate a substantial positive effect of GDP and energy consumption on all environmental quality indicators (EF, $\mathrm{CO}_{2}$ emissions and EPI). Furthermore, their study confirmed a two-way causality between the variables, with the exception of the GDP and $\mathrm{CO}_{2}$ and GDP and EPI pairs. For both of these cases, they only found evidence of unidirectional causality from GDP to both of these indicators. The researchers suggest that the "countries' economic development path and energy consumption patterns have started to align with their environmental policies" ([48], p. 212). Furthermore, the causal links between GDP and environmental quality indicators highlight the correlation between the path of economic growth and nature.

Another perspective including an assessment of the relationship between economy, society and ecology can also be found in a study published by Omri and Belaïd [21]. Their paper aimed to provide a more detailed perspective in relation to the assessment of the capacity of renewable energy to mitigate the negative impact of $\mathrm{CO}_{2}$ pollutions on social development and economic growth in 31 transitional economies during the transition years from 1990 to 2015. The results supported the argument that renewable energy might help achieve sustainable development goals for economies in the transitional period and might be applied to mitigate the negative impact of $\mathrm{CO}_{2}$ emission rates on social and economic growth. As the researchers have pointed out, renewable energy is therefore an extremely favourable investment opportunity from an economic and social standpoint.

Odabasi and Citlak [6] investigated the relationship between economic growth, electricity consumption and carbon dioxide emission parameters by analysing panel data from 20 European Union Member States that generated electricity with intensive fossil fuel combustion from 1995 to 2014. The results of the Dumitrescu-Hurlin panel causality test revealed unidirectional causality from economic growth to carbon dioxide emissions, from electricity consumption to carbon dioxide emissions and from economic growth to electricity consumption.

An additional contribution to this area of research has also been made in a paper by Ossowska and Janiszewska [16], where the authors evaluated the situation of 28 EU countries regarding sustainable energy consumption in 2017. For their analysis they used Eurostat data and six indicators: "primary energy consumption, final energy consumption, share of renewable energy in energy consumption, deficit/surplus in the 2020 RES consumption target, energy import dependency (\%), greenhouse gas emissions, intensity of energy consumption" ([16], p. 39). In their study, they divided the countries of the European Union into four groups based on their sustainable energy consumption situation. According to the results, the situation of twelve countries was identified as either favourable or rather favourable, while in the remaining sixteen members the situation have been classified as either rather unfavourable or unfavourable.

A study conducted by Loures and Ferreira [55] focused on the problem of $\mathrm{CO}_{2}$ issue in the European Union countries, considering the impact of different potential determinants on the increase of per capita emissions between 2010 and 2014. In an effort to identify main factors of growth of carbon dioxide emissions, the researchers utilised "a fuzzy-set qualitative comparative analysis- $f_{s} Q C A^{\prime \prime}$ ([55], p. 220), taking into consideration five macroeconomic factors: GDP growth, changes in the "share of private consumption, public consumption and investment consumption (all in relation to GDP) and energy consumption growth" ([55], p. 223). 
The study concluded that the major driver of emissions reductions was the economic crisis, for a direct correlation with economic growth was found. It was also discovered that energy consumption presents a close correlation with emission growth, on the other hand investment shows an opposite correlation, i.e., a higher share of investment in GDP is associated to emission reductions.

Meanwhile, Marra and Colantonio [8], in their study, analysed the drivers of increased utilisation of renewable energy sources, focusing on the role of socio-technical aspects such as stringent policy, lobbying, public awareness and education. They found that a combination of educational measures and raising public awareness of environmental issues could be used as a quick and strong follow-up to renewable energy deployment.

In conclusion, the available literature discloses that most of the empirical studies focused on the link between energy consumption and economic growth, and economic growth and environmental pollution and/or the relation with other economic factors, differ markedly and the results obtained as to the existence and direction of causality between the variables named have not been consistent or conclusive to date [2,43]. In the reviewed studies, researchers have analysed the indicated links in different contexts: temporal, spatial and statistical. The researchers have been guided by specific criteria and have considered a variety of time horizons, macroeconomic variables and datasets, both for individual countries and for groups of countries $[4,5,43]$. The empirical results also differ due to statistical methods and econometric techniques employed, etc. [2,13,45,49]. The inconclusive results might also be attributed to differences between individual countries (developing countries, transition economies and developed economies) [21]. After all, the EU consists of a heterogeneous group of countries that differ, for example, in their spatial conditions, availability of own energy sources, energy infrastructure, distribution system, energy pricing structure, share of carbon-intensive fuels in the energy mix and a variety of other factors [1,22]. This results in difficulties as far as a comparison of the findings and conclusions reached is concerned, which comparison would provide a starting point for making recommendations on political implications that might be followed in various countries.

\section{Conclusions}

Based on the present study, it can be concluded that European Union countries still vary significantly in terms of energy consumption and the distance between the countries consuming relatively the most (Luxembourg, Finland, Belgium) and the least (Romania, Malta, Croatia) energy is large. Nevertheless, the gap between the countries as regards energy consumption has narrowed slightly in the last decade, as has the consumption of energy itself, both primary and final, which is definitely a positive conclusion. As the results of the study have shown, countries with the highest energy consumption have relatively more often seen their energy consumption drop in the last decade than countries with lower energy consumption. This is confirmed by a significant correlation coefficient and the conclusion should be regarded as a positive aspect arising from the study. Energy consumption in individual sectors of the economy also varies significantly, with the highest consumption in the transport sector, followed by slightly lower consumption in the industrial and households sector and the lowest consumption in the commercial and public services sector. In the industrial, commercial and public services and households sector, energy consumption decreased between 2010 and 2019 but it increased in the transport sector, with countries such as Bulgaria, Lithuania, Hungary, Poland and Romania being the main contributors to this effect.

The share of renewable energy in energy consumption averages $20 \%$ in EU (27) countries. This share increased in all countries (except Hungary) over the period under analysis but the very wide gap between the countries which are leaders in the use of energy from renewable sources (Sweden, Finland, Austria) and those with the lowest share of this type of energy (Luxembourg, Malta, the Netherlands) still remains. Excessive and irrational usage of energy by society and the economy has a negative impact on 
environmental pollution. The share of greenhouse gas emissions from energy as a \% of total emissions in EU (27) countries is 75\%, with Estonia and Poland contributing the most to the pollution, and Ireland, Lithuania and Malta-the least. Estonia and Poland are also the only countries where greenhouse gas emissions from energy consumption have grown in the last decade and this shows them in a very bad light compared to other EU (27) Member States. The results of the correlation analysis have confirmed that countries that are significantly the major emitters of greenhouse gases from energy have increased their emissions even more in the last decade.

In addition, the analyses within this study have demonstrated that there is a significant positive correlation between all of the indicators characterising: total primary energy consumption, total final energy consumption and final energy consumption in individual sectors such as industry, transport, commercial and public services and households. This means that the same countries consume relatively the largest and the smallest amounts of energy overall and in individual economic sectors. Similar significant positive correlations and statements can be made with regard to the share of renewable energy in individual EU (27) countries.

One of the key conclusions reached as part of attainment of the objective of this study and verification of the hypothesis formulated at the beginning of the paper is the confirmation of the fact that there are significant positive correlations between the level of economic development of the EU (27) countries and primary and final energy consumption as well as energy consumption in individual sectors of the economy. Thus, it should be emphasised that the level of economic development of the countries significantly affects the level of energy consumption and the consumption significantly increases with the GDP growth of the country. It may also be concluded from the study that environmental pollution by EU (27) countries through the emission of greenhouse gases from energy increases with increasing consumption of primary and final energy and with decreasing consumption of renewable energy sources.

Conclusions from the studies can be helpful and provide suggestions for institutions and policy makers of individual EU countries in formulating new programme assumptions and implementing future activities in the design of energy system changes and energy policy. Such an approach is relevant for the development of a low-carbon economy. It deserves to be emphasised that striving for sustainable energy consumption is a long and difficult process. Therefore, further research is needed to identify the links between energy demand and consumption in general and in specific sectors of the economy, and the implementation of the long-term energy strategy of individual countries across Europe. This would allow to formulate significant implications and actions towards the development of renewable energy consumption and the improvement of energy use efficiency, hence the success of the energy transition, will become achievable.

Author Contributions: Conceptualization, A.K. and A.M.; methodology, A.K. and A.M.; software, A.K. and A.M.; validation, A.K. and A.M.; formal analysis, A.K. and A.M.; investigation, A.K. and A.M.; resources, A.K. and A.M.; data curation, A.K. and A.M.; writing-original draft preparation, A.K. and A.M.; writing-review and editing, A.K. and A.M.; visualization, A.K. and A.M.; supervision, A.K. and A.M.; project administration, A.K. and A.M. Both authors have read and agreed to the published version of the manuscript.

Funding: This research received no external funding.

Institutional Review Board Statement: Not applicable.

Informed Consent Statement: Not applicable.

Data Availability Statement: The data regarding total primary energy supply by fuel analysed in Introduction is publicly available datasets retrieved from the International Energy Agency (IEA). This data can be found here: https:/ / www.iea.org/reports/world-energy-balances-overview\#world, accessed on 30 March 2021. 
Acknowledgments: Disclosure statement: No potential conflict of interest was reported by the authors.

Conflicts of Interest: The authors declare no conflict of interest.

\section{References}

1. Šikić, T.F. The Impact of Energy Consumption on Economic Growth in Developed and Post-Transition Countries of European Union. Zb. Rad. Ekon. Fak. Au Rijeci 2020, 38, 475-497. [CrossRef]

2. Odugbesan, J.A.; Rjoub, H. Relationship Among Economic Growth, Energy Consumption, CO2 Emission, and Urbanization: Evidence From MINT Countries. SAGE Open 2020, 10. [CrossRef]

3. Szabo, J.; Fabok, M. Infrastructures and State-Building: Comparing the Energy Politics of the European Commission with the Governments of Hungary and Poland. Energy Policy 2020, 138, 111253. [CrossRef]

4. Belaïd, F.; Zrelli, M.H. Renewable and Non-Renewable Electricity Consumption, Environmental Degradation and Economic Development: Evidence from Mediterranean Countries. Energy Policy 2019, 133, 110929. [CrossRef]

5. Kahouli, B. Does Static and Dynamic Relationship between Economic Growth and Energy Consumption Exist in OECD Countries? Energy Rep. 2019, 5, 104-116. [CrossRef]

6. Odabasi, Y.; Citlak, U. Causality between economic growth, electrical energy consumption and carbon emission: An analysis on chosen EU countries. In Studies on Interdisciplinary Economics and Business; 2019; Volume 2, pp. 15-28. Available online: https:/ /www.researchgate.net/publication/338478521_Causality_between_Economic_Growth_Electrical_Energy_ Consumption_and_Carbon_Emission_An_Analysis_on_Chosen_EU_Countries1 (accessed on 30 March 2021).

7. International Energy Agency (IEA). Statistics Report. IEA World Energy Balances 2020: Overview. 2020. Available online: https: / / www.iea.org/reports/world-energy-balances-overview\#world (accessed on 30 March 2021).

8. Marra, A.; Colantonio, E. The Path to Renewable Energy Consumption in the European Union through Drivers and Barriers: A Panel Vector Autoregressive Approach. Socio Econ. Plan. Sci. 2020, 100958. [CrossRef]

9. Ahmed, K.; Rehman, M.U.; Ozturk, I. What Drives Carbon Dioxide Emissions in the Long-Run? Evidence from Selected South Asian Countries. Renew. Sustain. Energy Rev. 2017, 70, 1142-1153. [CrossRef]

10. Radmehr, R.; Henneberry, S.R.; Shayanmehr, S. Renewable Energy Consumption, CO2 Emissions, and Economic Growth Nexus: A Simultaneity Spatial Modeling Analysis of EU Countries. Struct. Chang. Econ. Dyn. 2021, 57, 13-27. [CrossRef]

11. Sterpu, M.; Soava, G.; Mehedintu, A. Impact of Economic Growth and Energy Consumption on Greenhouse Gas Emissions: Testing Environmental Curves Hypotheses on EU Countries. Sustainability 2018, 10, 3327. [CrossRef]

12. Khribich, A.; Kacem, R.H.; Dakhlaoui, A. Causality Nexus of Renewable Energy Consumption and Social Development: Evidence from High-Income Countries. Renew. Energy 2021, 169, 14-22. [CrossRef]

13. Butnaru, G.I.; Haller, A.-P.; Clipa, R.I.; Ştefănică, M.; Ifrim, M. The Nexus between Convergence of Conventional and Renewable Energy Consumption in the Present European Union States. Explorative Study on Parametric and Semi-Parametric Methods. Energies 2020, 13, 5272. [CrossRef]

14. Inês, C.; Guilherme, P.L.; Esther, M.-G.; Swantje, G.; Stephen, H.; Lars, H. Regulatory Challenges and Opportunities for Collective Renewable Energy Prosumers in the EU. Energy Policy 2020, 138, 111212. [CrossRef]

15. Sikkema, R.; Proskurina, S.; Banja, M.; Vakkilainen, E. How Can Solid Biomass Contribute to the EU's Renewable Energy Targets in 2020, 2030 and What Are the GHG Drivers and Safeguards in Energy- and Forestry Sectors? Renew. Energy 2021, 165, 758-772. [CrossRef]

16. Ossowska, L.J.; Janiszewska, D.A. Toward Sustainable Energy Consumption in the European Union. Polityka Energetyczna 2020, 23, 37-48. [CrossRef]

17. Al-Mulali, U.; Ozturk, I.; Lean, H.H. The Influence of Economic Growth, Urbanization, Trade Openness, Financial Development, and Renewable Energy on Pollution in Europe. Nat. Hazards 2015, 79, 621-644. [CrossRef]

18. Papież, M.; Śmiech, S.; Frodyma, K. Effects of Renewable Energy Sector Development on Electricity Consumption-Growth Nexus in the European Union. Renew. Sustain. Energy Rev. 2019, 113, 109276. [CrossRef]

19. Popescu, G.H.; Mieila, M.; Nica, E.; Andrei, J.V. The Emergence of the Effects and Determinants of the Energy Paradigm Changes on European Union Economy. Renew. Sustain. Energy Rev. 2018, 81, 768-774. [CrossRef]

20. Chica-Olmo, J.; Sari-Hassoun, S.; Moya-Fernández, P. Spatial Relationship between Economic Growth and Renewable Energy Consumption in 26 European Countries. Energy Econ. 2020, 92, 104962. [CrossRef]

21. Omri, A.; Belaiid, F. Does Renewable Energy Modulate the Negative Effect of Environmental Issues on the Socio-Economic Welfare? J. Environ. Manag. 2021, 278, 111483. [CrossRef]

22. Li, L.; Lin, J.; Wu, N.; Xie, S.; Meng, C.; Zheng, Y.; Wang, X.; Zhao, Y. Review and Outlook on the International Renewable Energy Development. Energy Built Environ. 2020. [CrossRef]

23. Caruso, G.; Colantonio, E.; Gattone, S.A. Relationships between Renewable Energy Consumption, Social Factors, and Health: A Panel Vector Auto Regression Analysis of a Cluster of 12 EU Countries. Sustainability 2020, 12, 2915. [CrossRef]

24. Child, M.; Kemfert, C.; Bogdanov, D.; Breyer, C. Flexible Electricity Generation, Grid Exchange and Storage for the Transition to a 100\% Renewable Energy System in Europe. Renew. Energy 2019, 139, 80-101. [CrossRef]

25. Dogan, E.; Aslan, A. Exploring the Relationship among CO2 Emissions, Real GDP, Energy Consumption and Tourism in the EU and Candidate Countries: Evidence from Panel Models Robust to Heterogeneity and Cross-Sectional Dependence. Renew. Sustain. Energy Rev. 2017, 77, 239-245. [CrossRef] 
26. Semple, S.; Jenkins, D. Variation of Energy Performance Certificate Assessments in the European Union. Energy Policy 2020, 137, 111127. [CrossRef]

27. Bel, G.; Joseph, S. Climate Change Mitigation and the Role of Technological Change: Impact on Selected Headline Targets of Europe's 2020 Climate and Energy Package. Renew. Sustain. Energy Rev. 2018, 82, 3798-3807. [CrossRef]

28. EU ETS Handbook. Available online: https://ec.europa.eu/clima/sites/default/files/docs/ets_handbook_en.pdf (accessed on 29 March 2021).

29. European Commission. Directive (EU) 2018/2001 of the European Parliament and of the Council of 11 December 2018 on the Promotion of the Use of Energy from Renewable Sources; (recast) (Text with EEA relevance). European Commission: Brussels, Belgium, 2018. Available online: https: / / eur-lex.europa.eu/eli/dir/2018/2001/2018-12-21 (accessed on 30 March 2021).

30. European Commission. Directive (EU) 2018/2002 of the European Parliament and of the Council of 11 December 2018 Amending Directive 2012/27/EU on Energy Efficiency; (Text with EEA relevance); European Commission: Brussels, Belgium, 2018; Available online: https: / / eur-lex.europa.eu/legal-content/EN/TXT/?uri=uriserv\%3AOJ.L_.2018.328.01.0210.01.ENG (accessed on 30 March 2021).

31. Directive (EU) 2019/944 of the European Parliament and of the Council of 5 June 2019 on Common Rules for the Internal Market for Electricity and Amending Directive 2012/27/EU (PE/10/2019/REV/1); European Commission. Available online: https: / / eur-lex.europa.eu/legal-content/EN/TXT/PDF/?uri=CELEX:32019L0944\&from=EN (accessed on 30 March 2021).

32. Leipprand, A.; Flachsland, C.; Pahle, M. Starting Low, Reaching High? Sequencing in EU Climate and Energy Policies. Environ. Innov. Soc. Transit. 2020, 37, 140-155. [CrossRef]

33. Directive 2003/87/EC of the European Parliament and of the Council of 13 October 2003 Establishing a Scheme for Greenhouse Gas Emission Allowance Trading within the Community and Amending Council Directive 96/61/EC. Available online: https: / / eur-lex.europa.eu/legal-content/EN/TXT/PDF/?uri=CELEX:32003L0087\&from=EN (accessed on 30 March 2021).

34. Del Río, P. Why Does the Combination of the European Union Emissions Trading Scheme and a Renewable Energy Target Makes Economic Sense? Renew. Sustain. Energy Rev. 2017, 74, 824-834. [CrossRef]

35. Directive (EU) 2018/410 of the European Parliament and of the Council of 14 March 2018 Amending Directive 2003/87/EC to Enhance Cost-Effective Emission Reductions and Low-Carbon Investments, and Decision (EU) 2015/1814. Available online: https:/ / eur-lex.europa.eu/legal-content/EN/TXT/PDF/?uri=CELEX:32018L0410\&from=EN (accessed on 30 March 2021).

36. Decision (EU) 2015/1814 of the European Parliament and of the Council of 6 October 2015 Concerning the Establishment and Operation of a Market Stability Reserve for the Union Greenhouse Gas Emission Trading Scheme and Amending Directive 2003/87/EC. Available online: https:/ / eur-lex.europa.eu/legal-content/EN/TXT/PDF/?uri=CELEX:32015D1814\&from=EN (accessed on 30 March 2021).

37. İskenderoğlu, Ö.; Akdağ, S. Comparison of Nuclear Energy and Renewable Energy Consumption in Terms of Energy Efficiency: An Analysis on the EU Members and Candidates. Int. J. Energy Econ. Policy 2019, 9, 193-198. [CrossRef]

38. Cabeça, A.S.; Henriques, C.O.; Figueira, J.R.; Silva, C.S. A Multicriteria Classification Approach for Assessing the Current Governance Capacities on Energy Efficiency in the European Union. Energy Policy 2021, 148, 111946. [CrossRef]

39. Communication from the Commission to the European Parliament, the European Council, the Council, the European Economic and Social Committee and the Committee of the Regions. The European Green Deal; European Commission. Available online: https:/ / eur-lex.europa.eu/legal-content/EN/TXT/?qid=1576150542719\&uri=COM\%3A2019\%3A640\%3AFIN (accessed on 30 March 2021).

40. Mastini, R.; Kallis, G.; Hickel, J. A Green New Deal without Growth? Ecol. Econ. 2021, 179, 106832. [CrossRef]

41. Alola, A.A.; Bekun, F.V.; Sarkodie, S.A. Dynamic Impact of Trade Policy, Economic Growth, Fertility Rate, Renewable and Non-Renewable Energy Consumption on Ecological Footprint in Europe. Sci. Total Environ. 2019, 685, 702-709. [CrossRef]

42. Eder, L.V.; Filimonova, I.; Nemov, V.; Provornaya, I. Forecasting Sustainable Development of Transport Sectors of Russia and EU: Energy Consumption and Efficiency. Int. J. Energy Econ. Policy 2018, 8, 74-80. Available online: https://www.zbw.eu/econisarchiv / bitstream/11159/2217/1/1023496127.pdf (accessed on 30 March 2021).

43. Acaravci, A.; Ozturk, I. On the Relationship between Energy Consumption, $\mathrm{CO}_{2}$ Emissions and Economic Growth in Europe. Energy 2010, 35, 5412-5420. [CrossRef]

44. Saint Akadiri, S.; Alola, A.A.; Akadiri, A.C.; Alola, U.V. Renewable Energy Consumption in EU-28 Countries: Policy toward Pollution Mitigation and Economic Sustainability. Energy Policy 2019, 132, 803-810. [CrossRef]

45. Soava, G.; Mehedintu, A.; Sterpu, M.; Raduteanu, M. Impact of Renewable Energy Consumption on Economic Growth: Evidence from European Union Countries. Technol. Econ. Dev. Econ. 2018, 24, 914-932. [CrossRef]

46. Smolović, J.C.; Muhadinović, M.; Radonjić, M.; Đurašković, J. How Does Renewable Energy Consumption Affect Economic Growth in the Traditional and New Member States of the European Union? Energy Rep. 2020, 6, 505-513. [CrossRef]

47. Topcu, E.; Altinoz, B.; Aslan, A. Global Evidence from the Link between Economic Growth, Natural Resources, Energy Consumption, and Gross Capital Formation. Resour. Policy 2020, 66, 101622. [CrossRef]

48. Ozcan, B.; Tzeremes, P.G.; Tzeremes, N.G. Energy Consumption, Economic Growth and Environmental Degradation in OECD Countries. Econ. Model. 2020, 84, 203-213. [CrossRef]

49. Waheed, R.; Sarwar, S.; Wei, C. The Survey of Economic Growth, Energy Consumption and Carbon Emission. Energy Rep. 2019, 5, 1103-1115. [CrossRef]

50. Khan, H.; Khan, I.; Binh, T.T. The Heterogeneity of Renewable Energy Consumption, Carbon Emission and Financial Development in the Globe: A Panel Quantile Regression Approach. Energy Rep. 2020, 6, 859-867. [CrossRef] 
51. Filimonova, I.V.; Provornaya, I.V.; Komarova, A.V.; Zemnukhova, E.A.; Mishenin, M.V. Influence of Economic Factors on the Environment in Countries with Different Levels of Development. Energy Rep. 2020, 6, 27-31. [CrossRef]

52. Bayar, Y.; Gavriletea, M.D.; Sauer, S.; Paun, D. Impact of Municipal Waste Recycling and Renewable Energy Consumption on CO2 Emissions across the European Union (EU) Member Countries. Sustainability 2021, 13, 656. [CrossRef]

53. Lapinskienè, G.; Peleckis, K.; Slavinskaitè, N. Energy Consumption, Economic Growth and Greenhouse Gas Emissions in the European Union Countries. J. Bus. Econ. Manag. 2017, 18, 1082-1097. [CrossRef]

54. Mahdi Ziaei, S. Effects of Financial Development Indicators on Energy Consumption and CO2 Emission of European, East Asian and Oceania Countries. Renew. Sustain. Energy Rev. 2015, 42, 752-759. [CrossRef]

55. Loures, L.; Ferreira, P. Energy Consumption as a Condition for per Capita Carbon Dioxide Emission Growth: The Results of a Qualitative Comparative Analysis in the European Union. Renew. Sustain. Energy Rev. 2019, 110, 220-225. [CrossRef]

56. Ahmad, T.; Zhang, D. A Critical Review of Comparative Global Historical Energy Consumption and Future Demand: The Story Told so Far. Energy Rep. 2020, 6, 1973-1991. [CrossRef]

57. Mussini, M. Inequality and Convergence in Energy Intensity in the European Union. Appl. Energy 2020, 261, 114371. [CrossRef]

58. Garrido-Prada, P.; Lenihan, H.; Doran, J.; Rammer, C.; Perez-Alaniz, M. Driving the Circular Economy through Public Environmental and Energy R\&D: Evidence from SMEs in the European Union. Ecol. Econ. 2021, 182, 106884. [CrossRef]

59. Lowitzsch, J.; Hoicka, C.E.; van Tulder, F.J. Renewable Energy Communities under the 2019 European Clean Energy PackageGovernance Model for the Energy Clusters of the Future? Renew. Sustain. Energy Rev. 2020, 122, 109489. [CrossRef]

60. Flores-Chamba, J.; López-Sánchez, M.; Ponce, P.; Guerrero-Riofrío, P.; Álvarez-García, J. Economic and Spatial Determinants of Energy Consumption in the European Union. Energies 2019, 12, 4118. [CrossRef]

61. Wittmayer, J.M.; Avelino, F.; Pel, B.; Campos, I. Contributing to Sustainable and Just Energy Systems? The Mainstreaming of Renewable Energy Prosumerism within and across Institutional Logics. Energy Policy 2021, 149, 112053. [CrossRef]

62. Mrówczyńska, M.; Skiba, M.; Bazan-Krzywoszańska, A.; Sztubecka, M. Household Standards and Socio-Economic Aspects as a Factor Determining Energy Consumption in the City. Appl. Energy 2020, 264, 114680. [CrossRef]

63. Dell'Anna, F. Green Jobs and Energy Efficiency as Strategies for Economic Growth and the Reduction of Environmental Impacts. Energy Policy 2021, 149, 112031. [CrossRef]

64. Balitskiy, S.; Bilan, Y.; Strielkowski, W.; Štreimikienè, D. Energy Efficiency and Natural Gas Consumption in the Context of Economic Development in the European Union. Renew. Sustain. Energy Rev. 2016, 55, 156-168. [CrossRef]

65. Bertoldi, P.; Mosconi, R. Do Energy Efficiency Policies Save Energy? A New Approach Based on Energy Policy Indicators (in the EU Member States). Energy Policy 2020, 139, 111320. [CrossRef]

66. Tenente, M.; Henriques, C.; da Silva, P.P. Eco-Efficiency Assessment of the Electricity Sector: Evidence from 28 European Union Countries. Econ. Anal. Policy 2020, 66, 293-314. [CrossRef]

67. Ahmadov, A.K.; van der Borg, C. Do Natural Resources Impede Renewable Energy Production in the EU? A Mixed-Methods Analysis. Energy Policy 2019, 126, 361-369. [CrossRef]

68. Escribano, G.; Paredes-Gazquez, J.; San-Martín, E. The European Union and the Good Governance of Energy Resources: Practicing What It Preaches? Energy Policy 2020, 147, 111884. [CrossRef]

69. Melliger, M.; Lilliestam, J. Effects of Coordinating Support Policy Changes on Renewable Power Investor Choices in Europe. Energy Policy 2021, 148, 111993. [CrossRef]

70. Mofijur, M.; Fattah, I.M.R.; Alam, M.A.; Islam, A.B.M.S.; Ong, H.C.; Rahman, S.M.A.; Najafi, G.; Ahmed, S.F.; Uddin, M.A.; Mahlia, T.M.I. Impact of COVID-19 on the Social, Economic, Environmental and Energy Domains: Lessons Learnt from a Global Pandemic. Sustain. Prod. Consum. 2021, 26, 343-359. [CrossRef]

71. Haar, L. An Empirical Analysis of the Fiscal Incidence of Renewable Energy Support in the European Union. Energy Policy 2020, 143, 111483. [CrossRef]

72. Soeiro, S.; Ferreira Dias, M. Renewable Energy Community and the European Energy Market: Main Motivations. Heliyon 2020, 6, e04511. [CrossRef]

73. Dagoumas, A.S.; Polemis, M.L.; Soursou, S.-E. Revisiting the Impact of Energy Prices on Economic Growth: Lessons Learned from the European Union. Econ. Anal. Policy 2020, 66, 85-95. [CrossRef]

74. Maya-Drysdale, D.; Jensen, L.K.; Mathiesen, B.V. Energy Vision Strategies for the EU Green New Deal: A Case Study of European Cities. Energies 2020, 13, 2194. [CrossRef]

75. Murawska, A.; Prus, P. The Progress of Sustainable Management of Ammonia Emissions from Agriculture in European Union States Including Poland-Variation, Trends, and Economic Conditions. Sustainability 2021, 13, 1035. [CrossRef]

76. Eurostat. Your Key to European Statistics. 2021. Available online: https://ec.europa.eu/eurostat/data/database (accessed on 4 February 2021).

77. International Organization for Standardization ISO. Country Codes_ISO 3166. 2019. Available online: https://www.iso.org/iso3166-country-codes.html (accessed on 4 February 2021).

78. Wysocki, F.; Lira, J. Statystyka Opisowa (Descriptive Statistics); Wydawnictwo Akademii Rolniczej im. Augusta Cieszkowskiego: Poznań, Poland, 2005.

79. Luszniewicz, A.; Słaby, T. Statystyka z Pakietem Komputerowym STATISTICA PL. Teoria $i$ Zastosowania (Statistics with the STATISTICA PL Computer Package. Theory and Applications); Wydawnictwo C.H. Beck: Warszawa, Poland, 2003. 